Portland State University

PDXScholar

Summer 9-20-2013

\title{
Gene Expression Life History Markers in a Hatchery and a Wild Population of Young-of-the-Year Oncorhynchus mykiss
}

Ian D. F. Garrett

Portland State University

Follow this and additional works at: https://pdxscholar.library.pdx.edu/open_access_etds

Part of the Aquaculture and Fisheries Commons, and the Genetics Commons Let us know how access to this document benefits you.

Recommended Citation

Garrett, Ian D. F., "Gene Expression Life History Markers in a Hatchery and a Wild Population of Young-ofthe-Year Oncorhynchus mykiss" (2013). Dissertations and Theses. Paper 1445.

https://doi.org/10.15760/etd.1444

This Thesis is brought to you for free and open access. It has been accepted for inclusion in Dissertations and Theses by an authorized administrator of PDXScholar. Please contact us if we can make this document more accessible: pdxscholar@pdx.edu. 
Gene Expression Life History Markers in a Hatchery and a Wild Population of Young-of-the-Year Oncorhynchus mykiss

by

Ian D. F. Garrett

A thesis submitted in partial fulfillment of the requirements for the degree of

\author{
Masters of Science \\ in \\ Biology
}

\title{
Thesis Committee: \\ Jason E. Podrabsky \\ Deborah Duffield
}

Kim Brown

Portland State University

2013 


\begin{abstract}
Life history within a single species can vary significantly. Many of these differences are associated with varying environmental conditions. Understanding what environmental conditions cue alternate life histories within a single species has been researched extensively. In salmonid fishes, more than almost any other group, varying environmental conditions give rise to individuals within species that take markedly different life history trajectories.

Oncorhynchus mykiss is a species of salmonid native to the Pacific Northwest region of North America. This species has two life history forms, anadromous and resident. The anadromous form spends a portion of its life in ocean while the resident life history form completes its entire life history in freshwater. Until the decision to migrate and morphological changes associated with smoltification occur, the two life history variants of this species are indistinguishable from each other. This ambiguity in juvenile $O$. mykiss morphology presents challenges for conservation managers charged with protecting and increasing threatened $O$. mykiss populations around the Pacific Northwest because conservation efforts cannot be evaluated until juvenile fish make the decision to migrate.

In this study microarray gene expression analysis was used to profile gene expression in juvenile populations of wild and hatchery $O$. mykiss to identify gene expression variation associated with alternate life history variants. This analysis identified 8 DNA sequences present in both brain and gill tissues that differ in expression in rainbow trout and steelhead hatchery stocks. Differential expression as quantified by microarray technology was validated with quantitative real-time PCR. Lastly, the expression of these putative life history markers was preliminarily evaluated in a wild population of $O$. mykiss at sample locations in the South Fork John Day River Basin, Oregon with known ratios of juvenile anadromous and resident fish.
\end{abstract}




\section{ACKNOWLEDGEMENTS}

First, I'd like to convey my sincere gratitude to my advisor, Jason Podrabsky for giving me advice, leadership, and support. The knowledge, and most importantly wisdom, I've learned from you has made me a better researcher and a better person. My time in your lab has been an important chapter of my life and has helped shaped me personally and professionally.

There are so many people that have helped with this research directly and indirectly. I'd to thank Brad Buckley for advising and mentoring me throughout my time at PSU. I'd like to thank my thesis committee Kim Brown and Deb Duffield for giving me advice and support. I'd like to thank Chris Jordan for your advice, support and for looking at my research in new and interesting ways and for making me look at the bigger picture.

Over the course of my time in the Podrabsky Lab my colleagues have become my friends and in one way or another have supported this research through advice, encouragement, and friendship; Marissa Lee, Amie Romney, Josiah Wagner, Greg Silver, Alicia Chivers, Claire Riggs, Kristin Culpepper, Andy McCracken, Camie Meller, Michael Knapp, Lindsay Henderson, Leah Tuor, Vicki Alla, Ben Pri-Tal, Stacy Vege, Isaac Sleadd, Amanda Kelley, Johnny Co, Kyle Mader, and many, many more.

I'd like to thank Cody Woll for assisting in the molecular biology portion of this thesis. I could not have gotten through all the samples collected for this project without your help.

I'd also like to thank Haley Ohms, for your friendship, advice, and for all the wonderful times in the field.

Finally, and most importantly I'd like to thank my partner Landon. Your support made this research achievable. I simply could have not done this without you. I'd like to thank my

mom, Wilma and my Aunt Kim and Uncle Wayne for always being there with kindness, and love. 


\section{TABLE OF CONTENTS}

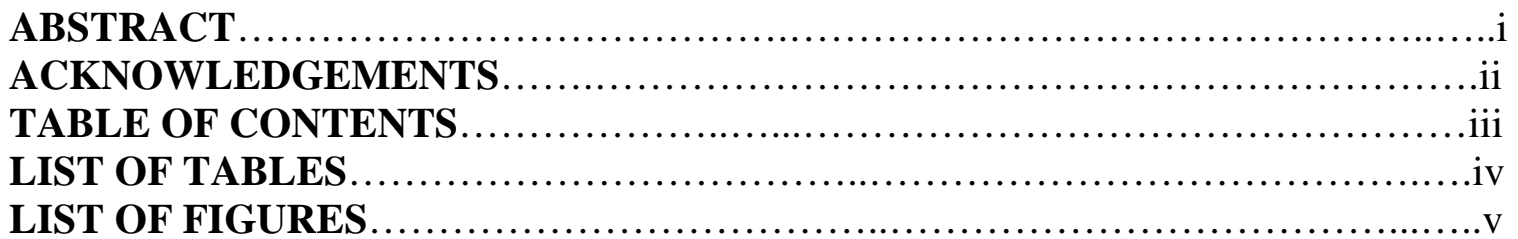

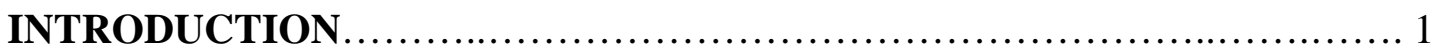

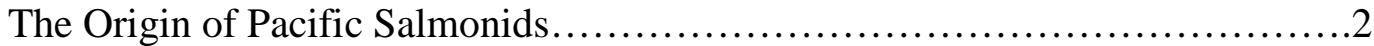

Life history variation in salmonid fishes......................................

Pacific Salmonid Impacts on the Ecosystem of the Pacific Northwest..............5

Life history of Oncorhynchus mykiss..........................................6

O. mykiss in the John Day River Basin, Oregon..................................

Hatchery Production of $O$. mykiss in the Columbia River Basin...................10

Conservation management of O. mykiss in the South Fork John Day..............12

Specific Aims...........................................................

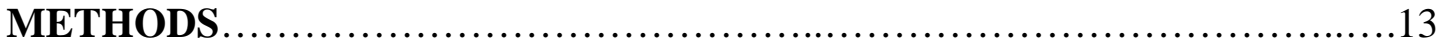

Specimen Collection and handling........................................ 13

Tissues Sampled........................................................ 16

RNA Extraction..........................................................

Microarray Probe Preparation............................................. 17

Microarray Hybridization................................................. 18

Microarray Analysis................................................... 18

Quantitative Real-time Polymerase Chain Reaction (qPCR)..................19

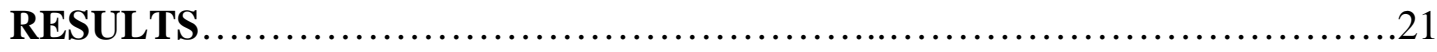

Gene expression patterns of hatchery stocks of $O$. mykiss.....................21

Quantitative Real-time PCR validation...................................22

Microarray analysis of gene expression in wild SFJD fish....................23

\section{DISCUSSION}

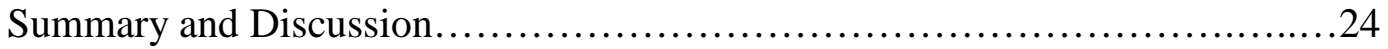

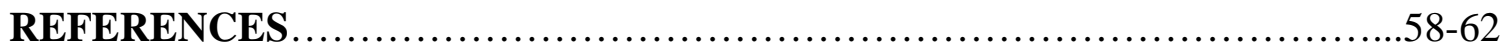




\section{LIST OF TABLES}

Table 1. Eight putative life history markers identified in the Mossy Rock Hatchery gene

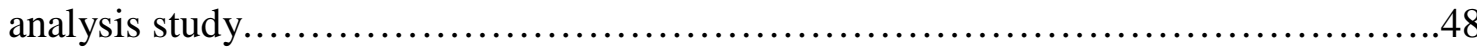

Table 2. Life history marker information: BT045730...........................49

Table 3. Life history marker information: NM_001123714.....................50

Table 4. Life history marker information: BT050202................................51

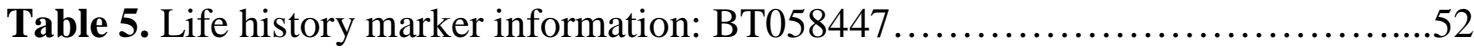

Table 6. Life history marker information: EG823395 ........................53

Table 7. Life history marker information: BT045799........................54

Table 8. Life history marker information: NM_001141601 .....................55

Table 9. Life history marker information: BT047975 ............................56

Table 10. Average $\mathrm{Ct}$ values for the 8 life history markers identified in this study for the Mossy Rock Hatchery samples..............................................57 


\section{LIST OF FIGURES}

Figure 1. Map of the South Fork John Day sample location........................31

Figure 2. Heat map of differentially expressed genes in gill tissue between hatchery rainbow trout and steelhead stocks.

Figure 3. Heat map of differentially expressed genes in brain tissue between hatchery rainbow trout and steelhead stocks.

Figure 4. Venn diagram of genes differentially expressed in gill and brain tissue from YOY Mossy rock hatchery stocks....

Figure 5. Heat map of gene expression for the 15 putative life history markers identified from the Mossy Rock Hatchery analysis.

Figure 6. Graph and correlations analysis of qPCR and Microarray gene expression data for the 8 selected life history markers.... .36

Figure 7. Heat map diagram comparing gene expression in gill tissues from South Fork John Day River basin samples site and Mossy Rock Hatchery stocks.

Figure 8. Heat map diagram comparing gene expression in brain tissues from South Fork John Day River basin samples site and Mossy Rock Hatchery stocks..................38

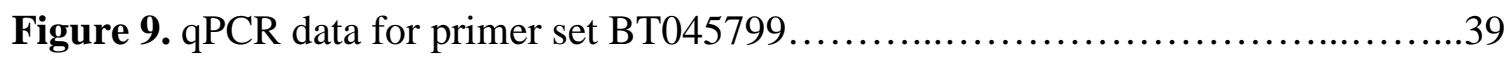

Figure 10. qPCR data for primer set BT045730............................40

Figure 11. qPCR data for primer set BT050202............................41

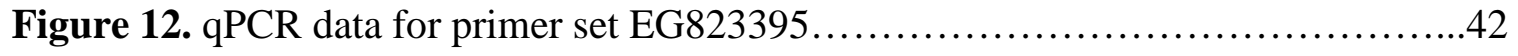

Figure 13 qPCR data for primer set BT047975.............................43

Figure 14. qPCR data for primer set $\beta$-actin................................ 44

Figure 15. qPCR data for primer set BT058447............................. 45

Figure 16. qPCR data for primer set NM_0023714 ............................46

Figure 17. qPCR data for primer set NM_001141601. 


\section{INTRODUCTION}

Salmonid fishes are a dominant part of marine and freshwater food webs in the northern Pacific Ocean and the river systems that drain into it. The reason for their great success is debatable, but very likely depends on their ability to exploit both freshwater and marine habitats, a trait that is rather rare amongst the fishes. The ability to exploit marine resources offers great advantages under certain circumstances, supporting large population sizes, increased growth rate, and increased adult size at reproduction (Gross et al., 1988; Hendry and Stearns, 2003; Jonsson and Jonsson, 1993). In addition, escape to the marine environment may allow populations to persist in times when freshwater habitat conditions are poor or lost due to ecological changes such as natural disasters. Alternately, in times when marine conditions are limiting, freshwater forms may sustain populations. Thus, it is not surprising that many salmonid species have evolved life history strategies that include migrating anadromous forms that exploit marine resources

prior to reproduction and non-migrating resident forms that complete their entire lifecycle in freshwater. Importantly, these life history variants appear to be indistinguishable genetically (Docker and Heath, 2003) and thus it is hypothesized that differential gene expression must underlie these observed patterns of life history diversity. Gene expression is known to be highly sensitive to varying environmental conditions in many organisms (Aubin-Horth et al., 2005) and vast differences in gene expression levels can lead to markedly different life history strategies between conspecific individuals associated with changes both morphologically and behaviorally (Evans and Wheeler, 
2001; Stearns, 1989). In this thesis, I evaluate differential gene expression in young-ofthe-year hatchery stocks of Oncorhynchus mykiss, resident: rainbow trout/anadromous: steelhead, known to differ in their migratory behavior, in an attempt to identify gene expression markers that are unique to anadromous and resident forms in salmonids.

\section{The Origin of Pacific Salmonids}

The genus Oncorhynchus is made up of seven salmonid species native to the Northern Pacific Ocean region of the Northern Hemisphere ranging from Northern Mexico on the North American side of the Pacific Ocean to South Korea and Southern Japan on the Asiatic side of the Pacific Ocean and are commonly referred to as "Pacific Salmon" (Quinn, 2005). These seven species include Chum (O. keta), Chinook ( $O$. tshawytscha), Sockeye (O. nerka), Coho (O. kisutch), Pink (O. gorbuscha), Steelhead (O. mykiss) and Coastal Cutthroat (O. clarki).

All seven species of Oncorhynchus are anadromous, spending part of their life history in the ocean but all spawning in freshwater. This obligate freshwater stage of salmonid life history has been argued to suggest the salmonid family has a freshwater evolutionary origin rather than seawater origin (Allendorf and Thorgaard, 1984). Three of the seven species, $O$. mykiss, $O$. clarki, and $O$. nerka have significant resident populations; populations that complete their entire life history completely in freshwater (these populations are commonly referred to as "trout") (Quinn, 2005).

Sequence differences in genes from Salmo salar (Atlantic salmon), O. mykiss and O. nerka suggest an estimated divergence between the genus Salmo and Oncorhynchus in 
the early Miocene period (approximately 20 MYA)(Devlin, 1993). Fossil evidence of Oncorhynchus is limited but the fossils that have been found date the radiation of Pacific salmonids between 20 and 6 MYA (McPhail, 1997; Stearly and R., 1993).

Oncorhynchus and Salmo differ greatly in that Oncorhynchus had a major radiation event producing the seven extant species we see today as well as several other that have since gone extinct (i.e. the Sabertooth salmon, O. rastrosus) while a major radiation event in Salmo never occurred. Fossil evidence suggests by 6 MYA all seven extant Oncorhynchus species had evolved to their current form (Stearly and R., 1993).

\section{Life History Variation in Salmonid Fishes}

Life history amongst the salmonid fishes has been extensively studied as a model to better understand how traits are inherited and maintained within and between populations. Salmonid life history typically takes two forms, resident and anadromous and is largely related to migration. The typical resident life history form is spawned in freshwater where it grows and completes its life cycle. The anadromous form is spawned in freshwater where it remains for many months to several years after which it begins morphological and physiological changes associated with a process known as smoltification in preparation for life in the ocean. (Hendry and Stearns, 2003)

Timing of smoltification varies between different species of salmonids. Some species such as Oncorhynchus keta (Chum salmon) have fry that migrate to the ocean within a few weeks of hatching (Quinn, 2005). Others like Oncorhynchus mykiss (Rainbow trout/steelhead) and Oncorhynchus kisutch (Coho salmon) have juveniles that 
reside for one to five years in freshwater before migrating to the sea (Quinn, 2005). Prior to seaward migration and smoltification, juvenile anadromous salmonids are termed parr. Parr are typically bottom dwelling pelagic fish that establish territories that they defend aggressively. Parr are indistinguishable in appearance from resident populations of the same species. Once parr establish territories they maintain their position in the stream by actively swimming against the current. A study done by Kutty and Saunders (1973) showed that Atlantic salmon parr (Salmo salar) placed in a swim chamber would swim against the current to exhaustion and collapse, while smolting fish placed in the same swim chamber and under the same conditions ceased swimming and showed no signs of fatigue or exhaustion. This suggests that a smolting fish will allow the current of a stream to carry them downstream and this refusal to swim could be seen as a characteristic of seaward migration. Behavioral changes are typically the first obvious cues that a fish has begun smoltification. Smolting fish typically abandon pelagic feeding territories, cease swimming, and express a marked decrease in aggression (Hoar, 1976). This decrease in aggression has been related to the observation that out-migrating fish tend to aggregate and eventually form schools for downstream migration.

Once in the ocean, anadromous fish experience rapid and substantial growth before returning to freshwater to spawn several years later (Hendry and Stearns, 2003). Among salmonids there exists degrees of anadromy ranging from species that are purely anadromous to those that are optionally anadromous (Hoar, 1976). Recent studies comparing the anadromous and resident (non-anadromy) life history forms of many salmonids species have suggested there may be genetic factors linked to life history, 
specifically related to smoltification (Narum et al., 2011; Nichols et al., 2008; Thrower et al., 2004). However, there has never been a study on gene expression associated with alternate life history variants within salmonids on fish prior to when the changes associated with smoltification, migration, or residency can be observed.

\section{Pacific Salmonids Impacts on the Ecosystems Pacific Northwest}

Ecologically Pacific salmonids play an important role in both oceanic and terrestrial ecosystems. In the Pacific ocean salmonids are an important food source, especially for many marine mammals (Pauly et al., 1998), and sea birds (Roth et al., 2007). Recent studies, done over the last decade have shown that returning anadromous salmonids also play a critical role in the nitrogen and carbon cycles in both the fresh water stream systems as well as the forests across the Pacific Northwest. It has also been shown that growth rates of resident population of salmonids in streams systems in Alaska were directly related to the nutrients anadromous salmonids carcasses brought to the stream systems from the oceans after the anadromous fish had spawned and died (Wipfil et al., 2003). As well as effects of animal communities salmonids have significant impacts on terrestrial plant ecosystems. An example of this is a study done by Helfield and Naiman (2001)that found Riparian forest near streams and rivers derive 22$24 \%$ of the foliar Nitrogen direct from spawning salmon. Ocean derived nitrogen brought to the freshwater ecosystems from spawning adult salmon has also been shown to be important in maintaining rearing grounds for juvenile salmonids. (Gresh et al., 2000) showed that only 6-7\% of the historic ocean derived nitrogen and phosphorus is 
reach Pacific Northwest streams. Without the input of large runs of anadromous fish, salmonid recovery efforts may be in vain.

\section{The Life History of Oncorhynchus mykiss}

An abundant and wide-spread species of salmonid native to the Pacific Northwest Region of North America, Oncorhynchus mykiss, is classified as optionally anadromous (Hoar, 1976). Within O. mykiss it is known that both the anadromous and resident life history forms can arise from parents of either life history trajectory (Christie et al., 2011; Thrower et al., 2004; Zimmerman and Reeves, 2000). A recent study done by Christie et al. (2011) tracked gene flow in a population of $O$. mykiss in the Hood River, Oregon. This showed that in the wild anadromous population of steelhead, nearly $20 \%$ of the alleles originated from resident rainbow trout parents (Christie et al., 2011). Other studies done by (Doucett et al., 1999; Zimmerman and Reeves, 2002) used evidence from strontium/calcium $(\mathrm{Sr} / \mathrm{Ca})$ ratios in otoliths to identify anadromous and non-anadromous individuals of $O$. mykiss in the Deschutes River, Oregon. Strontium is more common in salt water than in freshwater. Thus $\mathrm{Sr} / \mathrm{Ca}$ ratios can be used to determine whether or not an individual's mother was anadromous or non-anadromous due to maternal provisioning of these minerals into developing oocytes during oogenesis. Sr/Ca ratios indicate that in the Deschutes River, the anadromous steelhead sampled from the river had both anadromous and resident mothers (Zimmerman and Reeves, 2000). In addition, Sr/Ca ratios also suggest that resident $O$. mykiss in the Deschutes River had both anadromous and non-anadromous mothers (Zimmerman and Reeves, 2000). This study illustrates the 
lack of a purely genetic explanation for anadromy in $O$. mykiss from the Deschutes River, and instead implicates a non-genetic mechanism in determining life history variation in this species such as phenotypic plasticity associated with varying environmental cues. In addition, other studies show that the life history trajectory of $O$. mykiss is influenced by physiologic, environmental as well as genetic factors that play an important role in the decision to remain resident in freshwater or initiate changes required for smoltification and anadromy (Metcalfe et al., 1988; Nichols et al., 2008; Thrower et al., 2004).

While the genetic factors influencing life history are still poorly understood, several recent studies have focused on the genetic factors associated with smoltification at the population level using single nucleotide polymorphisms or SNPs (Narum et al., 2011) and quantitative trait loci (QTL) analyses (Nichols et al., 2008).

It is important to note that a recent study done by Brown et al. (2006) found intraspecific variation in $O$. mykiss mitochondrial genomes that suggests phylogenetic divide between coastal and inland populations. This phylogenetic difference between inland and coastal $O$. mykiss population is not well understood.

Very little is known concerning the mechanisms that determine alternative life history strategies in this species, and currently no reliable biomarkers are available for identifying alternative trajectories in young-of-the-year fish prior to the obvious changes associated with smoltification at an individual level. In addition, it is not clear at what point during early life history development the decision to become anadromous or resident is made in $O$. mykiss. Understanding when life history decisions are made, and identifying the gene expression pathways that underlie this decision will play an 
important role in better understanding how genetic and environmental factors interact to influence life history. This knowledge will not only inform scientists on the basic biology of salmonid species, but will also provide a powerful tool to inform resource managers concerned with the conservation of alternative life history forms in threatened O. mykiss populations.

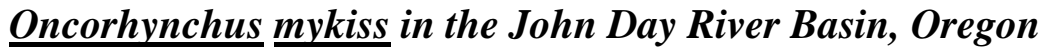

The John Day River is the second largest undammed river system in the American West and the largest free flowing river system in the continental United States to have an un-supplemented, wild, anadromous Oncorhynchus mykiss (steelhead) population (Carmichael and Talyor, 2010). This makes this population important due to its high degree of genetic diversity that has been relatively unaffected by genetic influences of hatchery fish. However, wild populations of $O$. mykiss have dramatically declined from historic levels in the Columbia River basin due to many factors, including overfishing, poor ocean conditions, habitat destruction, hydropower development and hatchery practices (Raymond, 1988). These declines led to the 1999 Endangered Species Act (ESA) listing of an environmentally significant unit (ESU) of steelhead from the Middle Columbia River as "threatened" (Federal Register, Vol. 64, No. 57, March 25, 1999, p. 14517),(Good and Waples). This ESU includes a wild population of summer-run steelhead in the South Fork John Day River Basin (SFJD).

Summer-run steelhead in the SFJD are characterized by adults returning to the main stem Columbia River from the Pacific Ocean in late-summer or early-fall and 
holding in the major river system over winter until spring when they migrate up the tributaries of the SFJD to spawn when river and stream flows increase. Oncorhynchus mykiss populations in the Columbia River Basin can spend from 1-5 years in freshwater before migrating; however migration generally occurs at year 2 or 3 (Peven et al., 1994). The SFJD population is iteroparous (spawning more than once per generation) and optionally anadromous, and thus is composed of both a migrant anadromous (steelhead) and a resident form (rainbow trout) that are morphologically indistinguishable as juveniles.

Previous research has identified anadromous/resident life history ratios in several tributaries of the SFJD basin through mark-recapture experiments. In this study two closely spaced tributaries (Figure 1) were found to have differences in the proportion of out-migrating juvenile fish (assumed to be anadromous). In 2004, Murderers Creek was shown to have a larger proportion of out migrant fish (13.7\%) compared to Black Canyon Creek (3.1\%) (Tattam, 2006). The following year (2005) $11.6 \%$ of tagged juvenile $O$. mykiss emigrated downstream from Murderers Creek compared to only $3.2 \%$ in Black Canyon Creek (Tattam, 2006). These two tributaries differ in their physical characteristics. Lower Murderers creek headwaters originate in the Malheur National Forest. Murderers Creek's elevation ranges from 900 to $2000 \mathrm{~m}$ and has a length of approximately $30 \mathrm{~km}$. The stream system primarily flows through open high desert grasslands and open range cattle pasture but at its higher elevations the landscape is dominated by Ponderosa and Douglas fir forests. Black Canyon Creek headwaters originate in the Black Canyon Wilderness Area inside the Ochoco National Forest. Black 
Canyon Creek's elevation ranges from 900 to $1600 \mathrm{~m}$ and has a stream length of approximately $15 \mathrm{~km}$. All $15 \mathrm{~km}$ of BCC are dominated by high gradient flow and most of the stream system flows in deep canyons dominated by scrub brush and ponderosa and Douglas fir forests. Stream temperatures in Murderers Creek range from $0^{\circ} \mathrm{C}$ in the winter to $26^{\circ} \mathrm{C}$ in the summer, while temperatures in Black Canyon Creek held around $1{ }^{\circ} \mathrm{C}$ in the winter and rarely reach over $20^{\circ} \mathrm{C}$ in the summer (Tattam, 2006). Despite these physical differences, the two stream systems enter the South Fork John Day River approximately $3.7 \mathrm{~km}$ from each other (Figure 1). These closely spaced tributaries with differing ratios of out-migrating fish create an excellent system for investigating possible differences in life history variation in a natural system.

\section{Hatchery Production of Oncorhynchus mykiss in the Columbia River Basin}

The culturing of $O$. mykiss in hatchery environments has its beginning in the early $20^{\text {th }}$ century at first as an attempt to create faster growing sport fish with high survival rates but later on as a tool to supplement declining wild $O$. mykiss populations (Service, 2010). As wild populations declined, limitations were put in place on the catch of wild fish resulting in a higher demand and therefore a greater production of hatchery fish throughout the region. Today, $70-80 \%$ of the salmon and steelhead caught in the Pacific Northwest originated from a hatchery (Service, 2010). As the numbers of hatchery $O$. mykiss released into the region's rivers and streams increased, concern of the effects of hatchery released fish on wild indigenous fish populations started to grow. Research suggests that hatchery fish are having direct and negative impacts on wild fish 
populations. For instance a study done by (McMichael et al., 1997) showed a significant correlation between the occurrence of residualized hatchery $O$. mykiss (anadromous released fish that do not migrate but instead remaining at their release site as resident fish) and negative growth rates in wild indigenous $O$. mykiss.

The $O$. mykiss anadromous life history form is the primary target for hatchery release programs in river and streams within the Columbia River Basin. Like most anadromous salmonids, O. mykiss exhibits "homing" during migration. (Quinn, 1993). They return to their natal rivers and streams to spawn. However, not all O. mykiss (wild and/or hatchery) return to their natal stream to spawn; these fish are termed "strays". Strays may migrate back to a nearby tributary or as far away as other river basins. For example, a study focusing on the occurrence of hatchery strays in Oregon coastal rivers found that $22 \%$ of fish sampled in 5 streams without hatchery $O$. mykiss releases were actually hatchery strays (Schroeder et al., 2001). These strays can have significant impact on the genetic make-up of protected wild $O$. mykiss populations especially when interbreeding between wild and hatchery fish occurs. Hatchery O. mykiss tend to have lower reproductive success than that of wild $O$. mykiss populations (Chilcote et al., 1986) as well as higher mortality rates. Hatchery $\mathrm{x}$ wild spawning pairs have been shown to produced $63 \%$ fewer recruits compared to wild $\mathrm{x}$ wild spawning pairs (Chilcote, 2003).

Despite the negative impacts of hatchery fish on wild populations, and the artificial rearing environment they create, hatchery fish provide an opportunity to perform "common garden" experiments in a much more controlled environment than can be accomplished in natural settings. In this study, we compared individuals from resident 
and anadromous hatchery stocks from Mossy Rock Hatchery, Washington. Mossy Rock Hatchery water is fed to the facility from an underground spring providing a clean water source with stable temperature of $10^{\circ} \mathrm{C}$ year-round.

A complete history of the origin of resident hatchery stock in the Pacific Northwest is partial at best. Of all the resident rainbow trout hatchery lines available, the line selected for this study (Goldendale Rainbow trout, GDT) has one of the better records of development. Goldendale Rainbow trout are fall spawning. The line began at Goldendale Hatchery in 1938. Today's Goldendale Rainbow trout line was established in 1948 and is a cross between Meader and Yakima rainbow trout lines (Kinunen and Moring, 1976). The anadromous Steelhead line used in this study is derived from wild fall run of Kalama River brood stock (ESA Listed) that has been long established at the Kalama Hatchery, Washington. The returning Kalama steelhead are spawned at the Kalama hatchery and incubated until the eggs reached the "eyed-up" stage of development before being transported to Mossy Rock Hatchery for hatching and rearing.

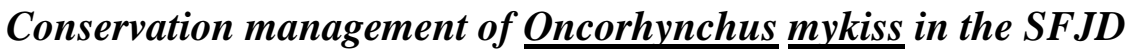

A major issue facing conservation of the SFJD O. mykiss populations is measuring the effectiveness of conservation strategies such as habitat restoration. The ESA listing of the Middle Columbia River ESU specifically targets only the anadromous form of the $O$. mykiss population. Both government and non-government agencies have recognized the importance of this John Day River Basin steelhead population and devoted large amounts of resources and time to habitat protection and restoration in 
hopes of increasing the steelhead populations. The ability to assess if conservation efforts are working to increase anadromous populations in restored areas could be a very useful management tool. Importantly, being able to identify pre-smolting juveniles as resident or anadromous would allow for more immediate impacts of management decisions to be assessed.

\section{Specific Aims}

The primary aim of this research is to identify differences in gene expression between known young-of-the-year (YOY) resident and anadromous forms of O. mykiss. I hope to use these differences in gene expression to identify gene expression markers that can be used to identify an individual $O$. mykiss YOY as likely to be anadromous or resident prior to any morphological, behavioral, or physiological changes associated with preparations for migration.

To achieve these aims oligonucleotide microarray gene expression and $\mathrm{qPCR}$ analyses were employed to identify gene expression differences between resident and anadromous life history variants in YOY O. mykiss reared under common conditions in a hatchery environment and in a wild, threatened population of juvenile $O$. mykiss from the South Fork John Day River Basin.

Gene expression differences were analyzed in brain and gill tissues between anadromous versus resident life history strategies by sampling juvenile, young of the year fish from Mossy Rock Hatchery, Washington, prior to smoltification. Gill and brain tissues have been chosen because of the important physiologic changes that occur within 
these tissues prior to smoltification and subsequent migration to the sea; because of this these tissues are an obvious location to observe differences in gene expression between alternate life history forms. Mossy Rock Hatchery was chosen as a sample location because the hatchery rears both a wild Kalama run anadromous population as well as a resident population. Both stocks of fish are brought to the hatchery at the same age and are rear under common garden conditions.

Next, gene expression was analyzed in brain and gill tissues from two different tributaries of the South Fork John Day River (Oregon) known to produce different ratios of anadromous versus resident forms independent of parental affects. Working in collaboration with a team from Oregon State University and under a permit from the National Oceanographic and Atmospheric Administration (NOAA) 


\section{MATERIALS AND METHODS}

\section{Specimen Collection and Handling}

Hatchery fish. Young-of-the-year O. mykiss were obtained from Mossy Rock hatchery (Mossyrock, Washington). Eight fish each from two stocks known to differ substantially in their tendency to migrate were sacrificed by concussion. The heads were then removed and flash-frozen in liquid nitrogen. Total time between sacrifice and freezing was less than $1 \mathrm{~min}$. Fish were randomly sampled from troughs, but chosen by size from the net to control for size-specific differences. This sampling resulted in a mean mass and mean length for the rainbow trout hatchery samples of $7.5 \pm 2.57 \mathrm{~g}$ and $85.25 \pm 10.54 \mathrm{~mm}$ (mean \pm s.d.), respectively. The steelhead sampling resulted in a mean mass and mean length for steelhead hatchery stock of $5.25 \pm 1.10 \mathrm{~g}$ and $79.75 \pm 2.95 \mathrm{~mm}$ (mean \pm s.d). Both the mean mass ( $\mathrm{t}$-test, $\mathrm{p}=0.13$ ) and mean length (t-test, $\mathrm{p}=0.31$ )

were not significantly different between the two stocks. The resident stock (MRHR) was a Goldendale Rainbow stock that had been reared for many generations at Mossy Rock hatchery for production of rainbow trout to support stocking efforts. The anadromous stock (MRHS) was produced from wild-origin Steelhead parents captured in the Kalama River for rearing in a hatchery environment for wild population supplementation.

Wild Fish. Young-of-the-year fish were sampled from two tributaries of the South Fork John Day River Basin (SFJD) that have been previously shown to produce differing proportions of anadromous and resident life history variants of juvenile $O$. mykiss (Tattam, 2006). These sites were Lowers Murderer Creek (LMC, anadromous 
biased) and Black Canyon Creek (BCC, resident biased). In a recent study Murderers Creek was shown to have juvenile growth rates significantly higher than Black Canyon Creek and Murderers Creek was shown to produce more migrant (assumed anadromous) O. mykiss as compared to Black Canyon Creek (Tattam, 2006).

Fish were captured by hook-and-line sampling at the BCC site, and by snorkel herding into seine nets at the LMC site. In both locations fish were sacrificed and whole heads were frozen as described above for the hatchery fish.

\section{Tissue Sampled}

Gill and brain tissue were sampled for both physiologic and practical reasons. First, many of the changes associated with smoltification occur in these two tissue types. Second, due to the limitation of lethal sampling of an ESA-listed species and the need to share fish among several investigators, only heads were available for sampling. The size class and weight class of hatchery fish chosen for this study were selected due to their similar size to YOY wild fish sampled in the South Fork John Day River basin research site.

\section{RNA Extraction}

RNA was extracted from brain and gill tissue by dissecting samples in the lab from frozen heads. Each frozen sample was homogenized in Trizol reagent and the RNA was extracted following the following the manufacture's protocol (Invitrogen, Carlsbad, CA, USA.). Care was taken to ensure that the tissues did not thaw prior to being 
submerged in Trizol reagent. Total RNA concentration and RNA purity were quantified using a Tecan Infinite 200 Pro Nanoquant plate reader (Mannedorf, Switzerland). RNA integrity was also verified by running $1 \mu \mathrm{g}$ of total RNA on a $1 \%$ agarose gel. All samples exhibited clear ribosomal RNA bands and a smear of high molecular weight RNA.

\section{Microarray Probe Preparation}

Differences in gene expression were quantified using an Agilent $44 \mathrm{~K}$ oligonucleotide array developed for Atlantic Salmon, Salmo salar, and commonly used to profile gene expression in salmonid fishes (www.agilent.com, Release Date 06/08). Probes were generated for each sample using $200 \mathrm{ng}$ of total RNA and the Agilent Onecolor spike mix kit according to the manufacturer's instructions. This kit provides 10 positive controls that act as quality control for the amplification and labeling steps preceding hybridization. Cyanine 3-CTP (Cy3) labeling dye was incorporated directly into the cRNA during the amplification process. Fluoresecently-labeled cRNA was then purified using RNeasy Minispin columns Qiagen (Valencia, CA, USA) following the

Qiagen protocol. Purified cRNA was eluted into a final volume of $30 \mu$ RNAase-free $\mathrm{H}_{2} 0$. cRNA yield was determined by measuring absorbance at $260 \mathrm{~nm}$ and labeling efficiency was calculated from total yield and total Cy3 fluorescence $(550 / 570 \mathrm{~nm}$ excitation/emission) according to Agilent's protocols using a Tecan Infinite Pro Nanoquant plate reader. Fluorescent-labeled probes with amplification yields greater 
than $1.65 \mu \mathrm{g}$ with specific activity greater than $6.0 \mathrm{pmol} \mathrm{Cy} 3 / \mu \mathrm{g}$ cRNA were used for microarray hybridizations.

\section{Microarray Hybridization}

cRNA samples were hybridized following Agilent's hybridization protocols. 1.65 $\mu \mathrm{g}$ of cRNA was processed with $25 \mathrm{x}$ fragmentation buffer to fragment the cRNA into optimal sizes for hybridization. Each sample was fragmented for exactly $30 \mathrm{~min}$ at $60.0^{\circ} \mathrm{C}$. Samples were then hybridized to the Agilent $4 \mathrm{x} 44 \mathrm{k}$ oligonucleotide microarrays using the Agilent SureHyb chamber at $65.0^{\circ} \mathrm{C}$ for $17 \mathrm{hrs}$.

\section{Microarray Analysis}

Each microarray was scanned using a Molecular Devices (Sunnyville, CA, USA) Axon GenePix 4000B Microarray scanner at $5 \mu \mathrm{m}$ resolution with an average of two scans per line. Images were acquired using the companion GenePix Pro 7 software. Images were then analyzed using Agilent Feature Extractor software following the software manufacture's protocols (version 9.5.3.1). Extracted data was exported to Agilent Genespring GX software (Ver 10) for expression analysis. Quality control analysis was performed on the results for all hybridizations, and one gill sample had to be excluded from analysis based on not meeting minimum standards. Genes that were differentially expressed in resident vs. anadromous life history variants were identified using a one-way ANOVA and the Benjamin Hochberg FDR correction for multiple comparisons (total $\mathrm{p}<0.05$ ). Further filtering of the data analysis by fold-change in gene 
expression was sometimes performed to highlight genes with high levels of gene expression variation. A clustering analysis was performed on the genes found to be differentially expressed using non-averaged samples and a hierarchical clustering algorithm with a Pearson centered distance metric and a centroid linkage rule. Clusters were based on both entities and condition (i.e. gene probe and stock). Venn diagrams were constructed using the entity lists generated from the one-way ANOVA statistical test comparing differentially expressed genes in both tissue types. Genes differentially expressed in both tissue types were deemed candidate life history markers. The full sequence for each candidate life history marker was downloaded from GenBank using the nucleotide Blast tool (http://blast.ncbi.nlm.nih.gov/) using the accession numbers for each maker found in the microarray annotation file provided by Agilent.

\section{Quantitative Real-time Polymerase Chain Reaction (qPCR)}

Microarray data were validated using qPCR for probes that appeared to be possible markers for life history variation in $O$. mykiss. PCR primers were designed using the National Center for Biotechnology Information Primer-Blast website (http://www.ncbi.nlm.nih.gov/tools/primer-blast/) based on the accession number for each probe found in the Agilent S. Salar microarray annotation file. Information about each primer set is shown in Tables 1-9. Primers were selected for product lengths between 75 and $150 \mathrm{bp}$. Optimal annealing temperatures (Table 10) were calculated using New England Biolabs (Ipswich, MA, USA) Tm calculator (http://www.neb.com/nebecomm/tech_reference/tmcalc/default.asp\#.T-1WprVDx8G) 
which accounts for the annealing temperatures for each individual primer set within the buffers and reagents associated with their PCR assay. Single-stranded cDNA was synthesized using the Thermo Scientific Fermentas (Glen Burnie, Maryland) first strand cDNA synthesis kit according to the manufacturer's instructions. Standard PCR reactions were performed using New England Biolabs reagents on each primer set to optimize reaction protocols. PCR product purity was checked electrophoretically on a $2 \%$ agarose gel. Finalized PCR programs used for qPCR quantification of each probe are reported in Tables 2 and 3. qPCR reactions were run on a Bio-Rad (Hercules, CA, USA) MiniOpticon real time PCR System using QuantiTect SYBR green PCR Master mix (Qiagen - Catalog\#204143). Data were collected and $\mathrm{C}_{\mathrm{t}}$ values were calculated with the companion Opticon Monitor software (version 3.1.32) (See Figures 13-21). Comparative quantification was used using the $\Delta \Delta \mathrm{C}_{\mathrm{t}}$ method (Invitrogen, 2012). (Fold Change = $\left.\mathrm{EffS}_{\mathrm{Sample}}^{\Delta \mathrm{Ct} \text { Sample}} / \mathrm{Eff}_{\text {Normalizer }}^{\Delta \mathrm{CtNorm}}\right)($ See Table 10) using $\beta$-actin as the reference for each comparison. 


\section{RESULTS}

\section{Gene expression patterns of hatchery stocks}

Microarray analysis revealed 154 sequences differentially expressed in the brain tissue and 137 sequences differentially expressed in gill tissue between hatchery rainbow trout stocks and hatchery-reared wild steelhead stocks. Heat maps generated from the hierarchical clustering analysis of differentially expressed sequences illustrate a clear relationship between gene expression and stock type as seen in Figures 2 and 3. Of the 15 differentially expressed sequences common to gill and brain tissues (Fig 4 and 5), 8 sequences had known accession numbers and full sequences were obtained from GenBank (Table 1). These 8 sequences were chosen as putative life history markers for resident versus anadromous life history variants in YOY O. mykiss. Three of the eight

life history markers are known genes, proteasome subunit beta type-9b, cd83 protein, and duodenase-1 (Table 1). Little is known about the role these genes have on alternate life history pathways but it is clear from the microarray data that the genes are alternately expressed between the two different life history types. Gene Ontology interrogation of the data resulted in no enrichment of differentially expressed genes for any specific pathway. However, this negative result is likely due mainly to the limited annotation of the $S$. salar genome and associated microarray probes represented on the microarray. 


\section{Quantitative real-time PCR Validation}

Primer sets for each accession number resulted in verified PCR protocols that yielded single products of the appropriate size (Tables 2-10) as verified on $2 \%$ agarose gels. These verified PCR protocols were then used to validate the microarray data using qPCR for each gene expression marker. The Results for these qPCR runs are presented in Fig 7-15)

There was a significant positive correlation between the qPCR and microarray expression data for all eight markers. $(r=0.72, p<0.001$; Fig 16). These data validate the microarray gene expression data generated in this study by demonstrating a direct correlation between qPCR data and microarray data as seen in Figure 16. Linear regression analysis yields a slope close to 1.0 , suggesting a nearly 1:1 relationship between the two methods of determining gene expression (slope $=0.93 \pm 0.24, \mathrm{p}<0.002$ )

The most significant differentially expressed marker in both brain and gill tissue was marker BT045730. For this marker, microarray analysis yielded a 8.02-fold up regulation in rainbow trout brain, while qPCR analysis using $\mathrm{C}_{\mathrm{t}}$ values yielded a 16.28fold up regulation in the same sample. For the same marker in gill tissue the microarray analysis yielded an 8.40-fold up regulation, while qPCR yielded a 14.27-fold up regulation. Thus, the microarray and qPCR results are consistent in both direction and magnitude of differential expression. These data indicate with some certainty that these markers were differentially expressed between the two life history stocks reared under identical hatchery conditions. 


\section{Microarray analysis of gene expression in wild fish}

The microarray analysis comparing LMC, BCC, MRHR to MRHS in brain tissue revealed 154 differentially expressed genes (Fig. 3). For gill tissue, 137 genes were differentially expressed (Fig. 2). Cluster analysis on these differentially expressed sequences in brain and gill tissue sampled from all sample locations (MRHS vs. MRHR vs. LMC vs. BCC) reveal expression patterns that are unique in wild compared to hatchery fish suggesting a large component of differential gene expression due to environmental an ecological differences between the wild and hatchery stocks. (Fig. 2-3). However, despite all of this variation, two of the eight potential life history markers identified as differentially expressed in hatchery stocks were also differentially expressed in the wild fish. These two markers' accession numbers are: BT045730, and BT047975. 


\section{DISCUSSION}

The complexity of life history variants observed in extant populations of $O$. mykiss are very likely the result of selective pressures that vary over time and in intensity alternately favoring increased survival in marine and freshwater environments. Thus, the life history matrix of these fish remains flexible and able to adapt to favorable ocean or freshwater conditions. While this is clearly of evolutionary advantage, it almost certainly adds layers of complexity to the natural fluctuations in population size that are observed even in wild and undisturbed populations of fish. When human manipulations of populations and degradation of the environment (both freshwater and marine) are added to the mix, determining the causes behind population declines and expansions can be very difficult. In addition, without knowledge of the environmental factors that regulate life history decisions and the molecular pathways that are altered in resident versus anadromous variants, it is extremely difficult to predict changes in fish health or abundance over time and in response to changes in the environment. Thus, as a first step towards identifying the molecular pathways that are involved in determining life history variation in $O$. mykiss I have used gene expression analysis to identify genes that are differentially expressed in stocks of fish that are known to be primarily resident or anadromous, but were reared under identical conditions. This "common garden" experimental design provides the best conditions for identifying genes that are differentially expressed due to life history trajectory, and not local environmental conditions. It is our hope that these genes will be useful for two distinct purposes - first, 
of empirical value, and second, for the practical value for the management of threatened populations. First, I hope to identify the molecular pathways that regulate life history trajectories in this species, and the window of development in which life history trajectory is determined. This information will be invaluable in understanding how environmental and genetic factors work together to determine complex life history decisions. Second, it is hoped that the life history markers identified in this gene expression study could be used to develop molecular markers that can predict life history trajectory using a non-lethal sampling protocol in pre-smolting juveniles from both wild populations and hatchery stocks. This information can be used to determine areas where resident and anadromous variants are highly successful, which is information sorely needed in preparing management strategies for protecting endangered populations of anadromous $O$. mykiss in the Columbia River Basin.

There are many factors that have been identified as influencing life history decisions in $O$. mykiss and other populations of salmonids but the three widely accepted indicators of life history are growth-rate (Hutchings and Jones, 1998), (Metcalfe et al., 1999) movement/migration (Beckman et al., 1998) and survival (Holtby et al., 1990). These three indicators are interdependent and culminate in an individual's "decision" to mature in freshwater (resident fish) or migrate to sea (anadromous fish). These factors can be measured over long periods of time. However, these indicators are all large-scale traits that integrate changes in many physiological systems, and likely represent the downstream effects of the actual mechanistic causes that drive the changes associated with life history variation. In this thesis, I argue that gene expression changes prior to the 
expression of the above mentioned life history indicators and that by focusing on the role that these genes play in regulating cellular and organismal physiology, we can not only quickly and easily identify a juvenile $O$. mykiss's likely life history in a very short period of time, but we can also ultimately understand how and perhaps why the life history decision has been made.

In this study over 150 genes have been identified that are differentially expressed in resident versus anadromous hatchery stocks of $O$. mykiss. Of the 8 identified sequences selected as putative life history markers in hatchery stocks, several of these sequences are also differently expressed between South Fork John Day River sample sites. At this point, there is no cohesive story that can be told based on the genes that have been identified. This is not a failure of the methodologies used, but rather is a symptom of our general lack of knowledge of gene function for the genes that are differentially expressed. The major focus of this study was to primarily identify genes associated with alternate life histories in juvenile $O$. mykiss but preliminary research shows the functions of the eight identified life history genes in this study are, at this point, poorly understood. However, the association with three major physiologic processes (proteasome activity, metabolism, digestion and immune response) has been established for all but one of these markers (Accession \# EG823395).

Markers NM_001123714, BT047975 and BT058447 have been shown associated with proteasome function (Murray et al., 1999). BT050202, BT045730, NM_001141601 have been shown to be associated with metabolisms and specifically markers BT050202 (gene ID/name: ddn1, Duodenase-1) is a protease which has both trypsin-like and 
chymotrypsin-like activities (Pletnev et al., 2000). Finally, BT045799 (GeneID/name: CD83, CD83 Protein) have been shown to be involved in immune response. Specifically CD83 is a protein in the family of immunoglobulin superfamily of receptors. It is thought to be involved in the regulation of antigen presentation and may also be involved in binding to dendritic cells to inhibit the cell's maturation (Chen et al., 2011). How these genes affect life history decisions in $O$. mykiss are unknown at this point.

Additional studies will be required to better understand the role these genes have in life history decisions. Many of the other 150 genes that are differentially expressed are also of unknown identity and or function. It will take many years to identify and determine the function of these genes, and hopefully after a great deal of effort we will be able to reconstruct a mechanistic picture of the molecular differences between a fish that expresses as a resident or anadromous life history variant. These genes are the first clues to unraveling a likely complex interaction of gene expression that leads to the differences in cellular and organismal traits we associate with both life history variants.

From a practical perspective, these differentially expressed genes represent putative biomarkers for anadromous and resident life history variants of $O$. mykiss in the two hatchery populations in this study. Importantly, these markers are expressed far prior to the morphological and physiological changes that are associated with smoltification. Identifying these markers in non-lethal tissue would make it possible to use them to identify life history trajectory in YOY wild $O$. mykiss populations. This will make possible the ability to look for changes in the ratio of anadromous to resident forms in specific stream reaches and in response to specific alterations in the environment, such as 
fluctuations in temperature or changes in fish density, food quality and availability. These life history markers may also play an important role for conservation managers when evaluating habitat restoration projects. Life history markers could allow fish to be examined soon after these events which will minimize loss of the signal due to migration of fish out of an area, and it will allow a greater deal of certainty to be developed as to cause and effect relationships in migratory decisions by individual fish. In the future we may not have to wait for fish to smolt and migrate in order to determine the effects of habitat alterations on the ratio of anadromous versus resident forms.

The expression analysis of the two Mossy Rock Hatchery stocks (rainbow trout/steelhead) demonstrate there is an expression level difference between these two long establish hatchery stocks. Microarray data and qPCR data are closely correlated and both support the same conclusion of differential expression in the two stocks.

From a hatchery perspective the ability to identify the life history of juvenile fish prior to their release into local rivers and streams could alleviate many of the problems associated with residual and stray fish. The common garden conditions of Mossy Rock hatchery would be an ideal place to test whether these anadromy markers do fully predict a juvenile $O$. mykiss life history. Expression analysis of these markers could be performed on fin clips that are produced as a normal part of the PIT-tagging efforts throughout the Columbia River basin. The migration of these fish could then be easily tracked through existing PIT tag monitoring stations at all major dams and by placing new PIT tag monitoring stations at strategic sites along the fish's migration route. These 
data could be used to validate the identified gene expression markers in fish released into natural waterways.

The sample size of this study is relatively low and was limited by the need to lethally sample an ESA listed population of fish. The future application of these markers for the management of wild populations will require additional studies to not only validate the results found in this study in broader populations of $O$. mykiss, but also to validate that these markers can be identified in non-lethal tissue samples. Preliminary data suggested at least one of the identified life history markers (BT045730) is expressed and can be quantified in a non-lethal tissue sample (fin clip). The ability to use fin-clips to identify future migratory behavior could provide higher resolution data on specific reaches of stream systems and provide information on how management practices are affecting the ratio of anadromous and resident forms of $O$. mykiss. It would provide a powerful tool to help in habitat restoration monitoring of ESA and non-ESA population of O. mykiss.

Migration behavior in $O$. mykiss from the South Fork John Day River basin has been monitored using Passive Integrated Transponders (PIT) Tags (Tattam, 2006). This study, although limited in scope and sample size illustrated differing ratios of migrant and resident juvenile $O$. mykiss in stream systems within the basin. In the future, it would be fantastic to compare the anadromous/resident ratios from tributaries with known differences in migration bias with the putative gene expression markers identified in this study. Non-lethal sampling and PIT tagging of a large number of individuals in a natural setting such as this would be an excellent way to validate the life history markers from 
this study. In fact, this is the logical next step in evaluating the effectiveness of these markers.

The ability to identify what life history strategy (anadromous or resident) young of the year $O$. mykiss are expressing before there are morphological differences between individual fish has never been achieved. This study is the first to identify life history markers present in multiple tissues types that may be useful tools for understanding the mechanisms that induce life history variation, as well as a way to evaluate life history variation in this species. Further research into using these markers for verification via non-lethal sampling (blood samples or fin clips) is the next logical step in furthering this research. In addition, evaluating how early in development these differences in gene expression can be traced will help better understand the timing of the decision to follow a specific life history trajectory. 


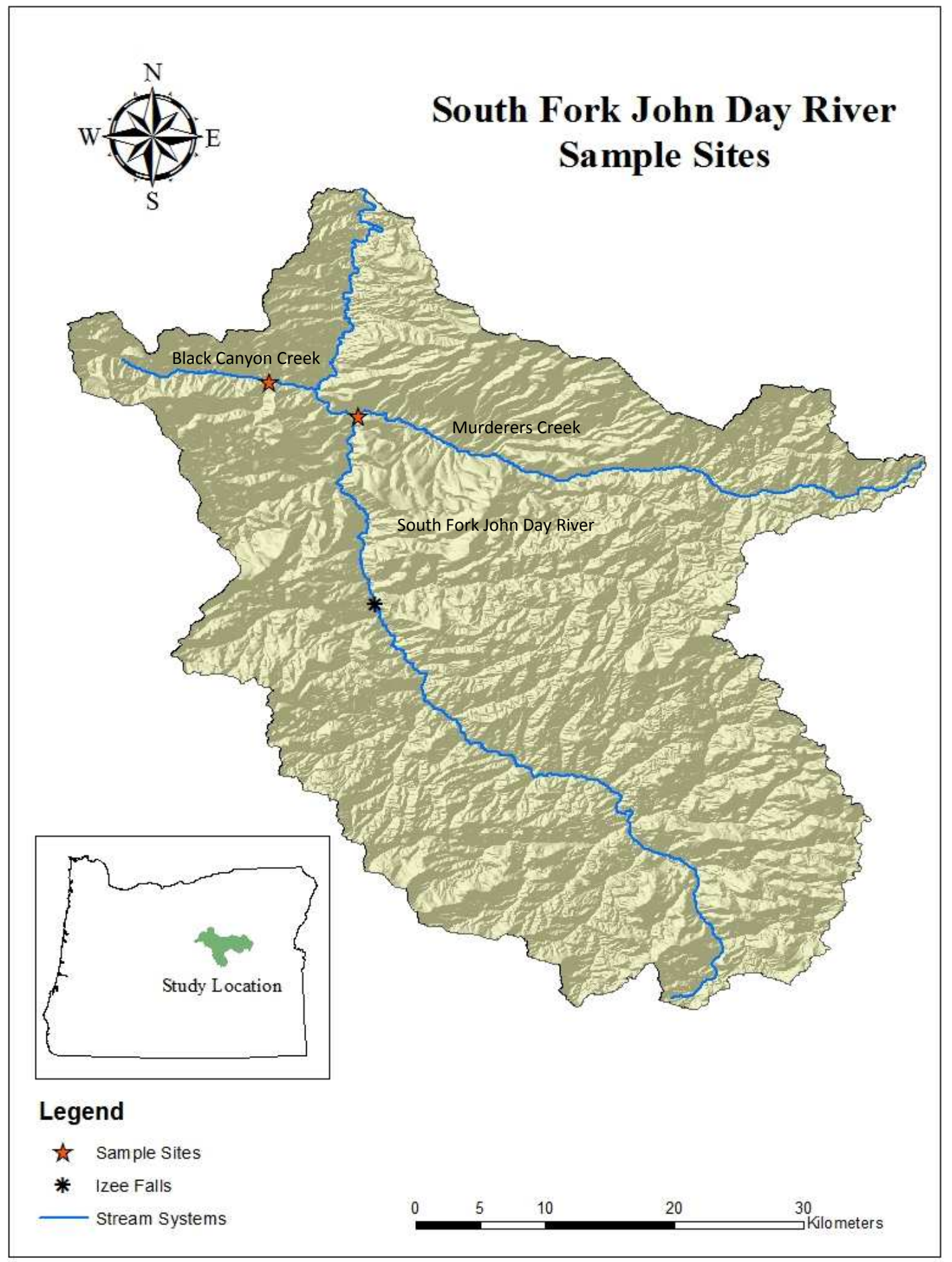

Figure 1. Map of the South Fork John Day Sample Locations 


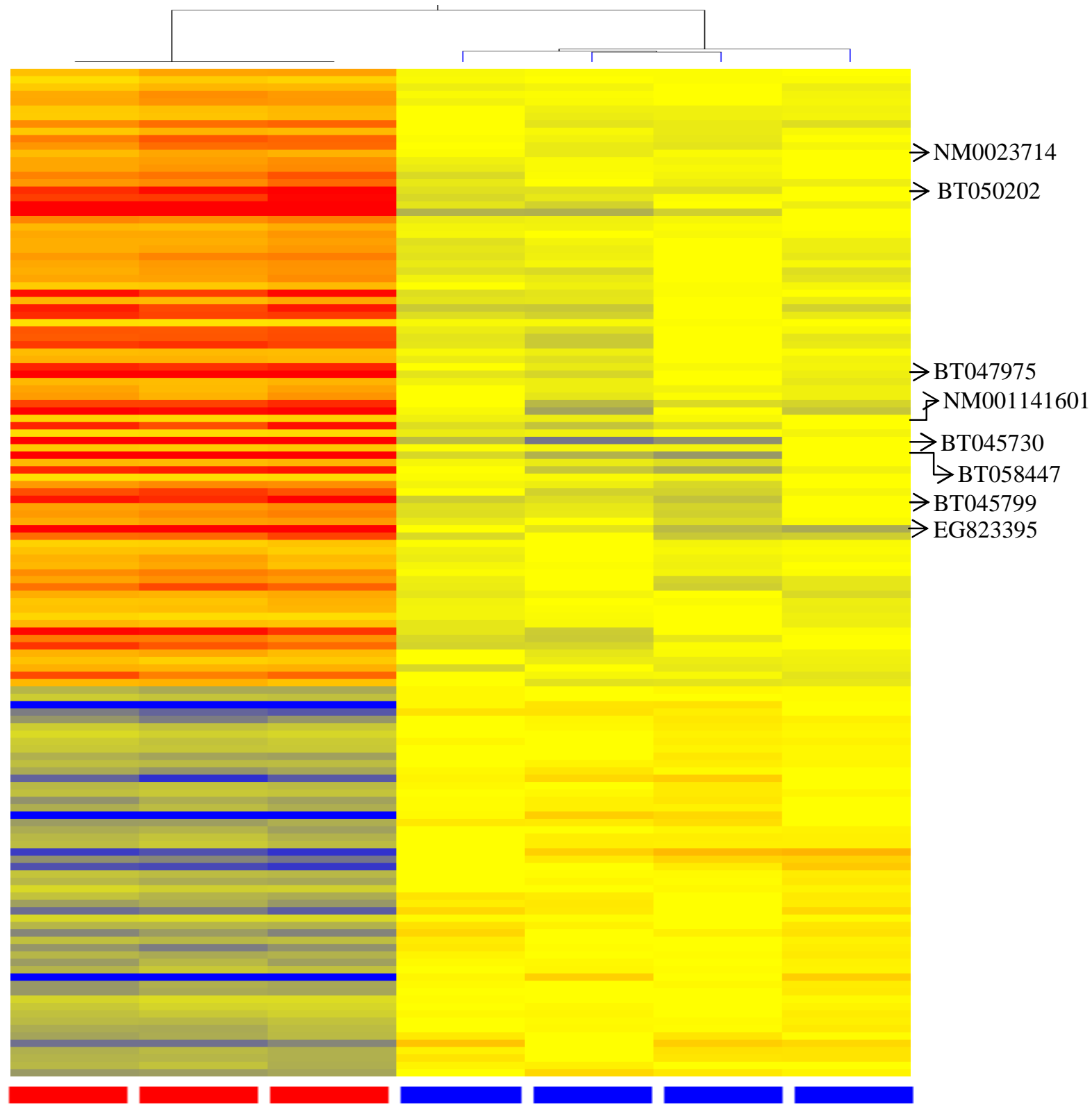

Figure 2. Heat Map of differentially expressed gene in gill tissue between hatchery rainbow trout and steelhead stocks.

Cluster analysis (Pearson's Centered) of all genes differentially expressed in gill tissues between youngof-the-year hatchery steelhead (MRHS) and hatchery rainbow trout (MRHR) stocks. There were 137 differentially expressed genes identified using t-tests and the Benjamini-Hochberg correction for multiple comparisons (total $\mathrm{p}<0.05$ ).

Legend - Hierarchical Combined Tree on SampleLOC (Non-averaged)

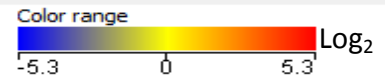

SampleLOC

- MRHR

- MRHS 


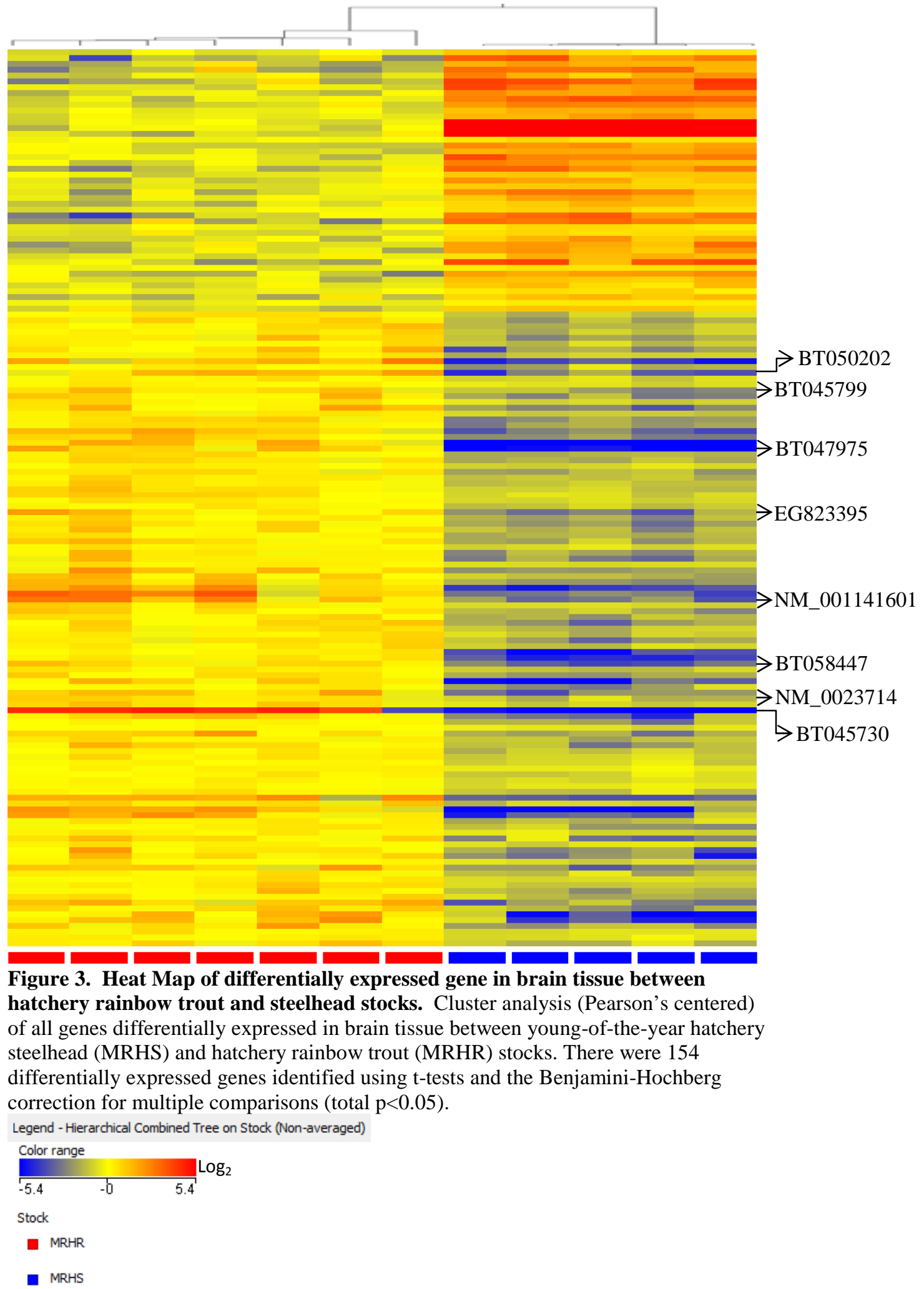




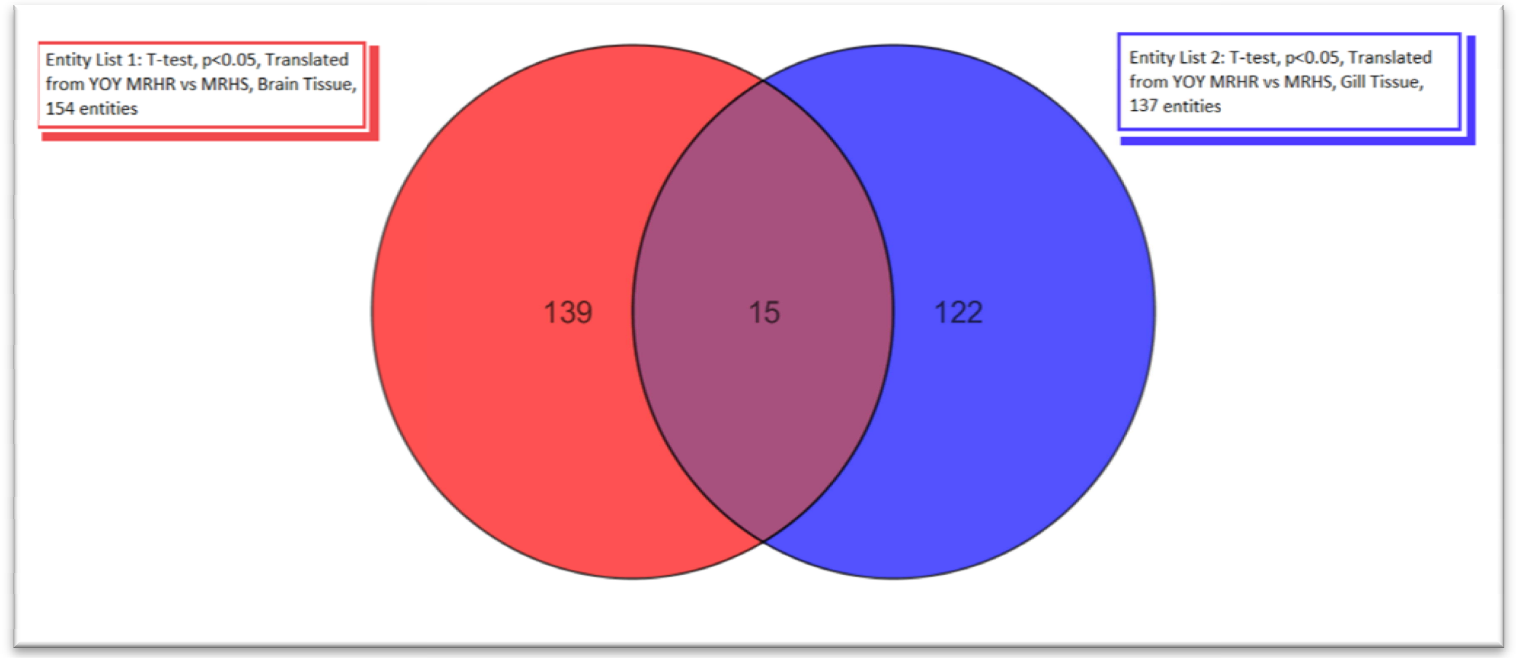

Figure 4. Venn diagram of genes differentially expressed in gill and brain tissue from young-of-the-year Mossy Rock Hatchery stocks.

(MRHS: Mossy Rock Hatchery steelhead, MRHR: Mossy Rock Hatchery rainbow Trout). 15 genes were differentially expressed in both brain and gill tissues and have been chosen as putative life history markers for anadromous versus resident forms of O. mykiss. 
Gill Tissue

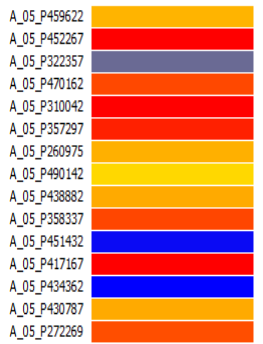

RT

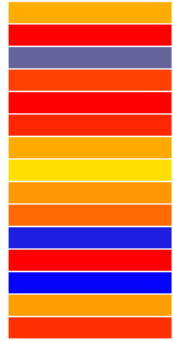

RT

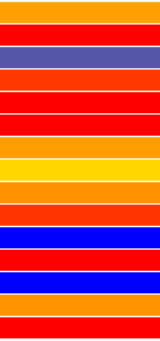

RT

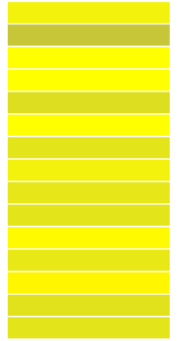

$\mathrm{SH}$

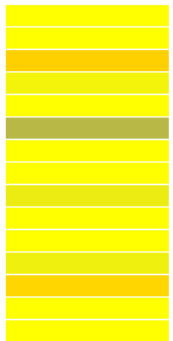

$\mathrm{SH}$

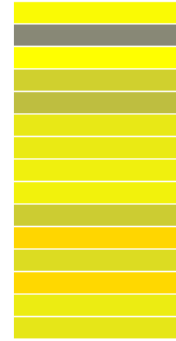

$\mathrm{SH}$

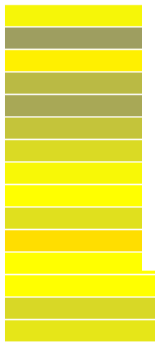

$\mathrm{SH}$

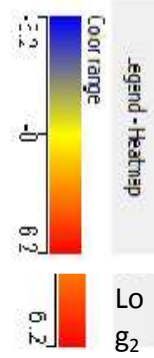

\section{Brain Tissue}

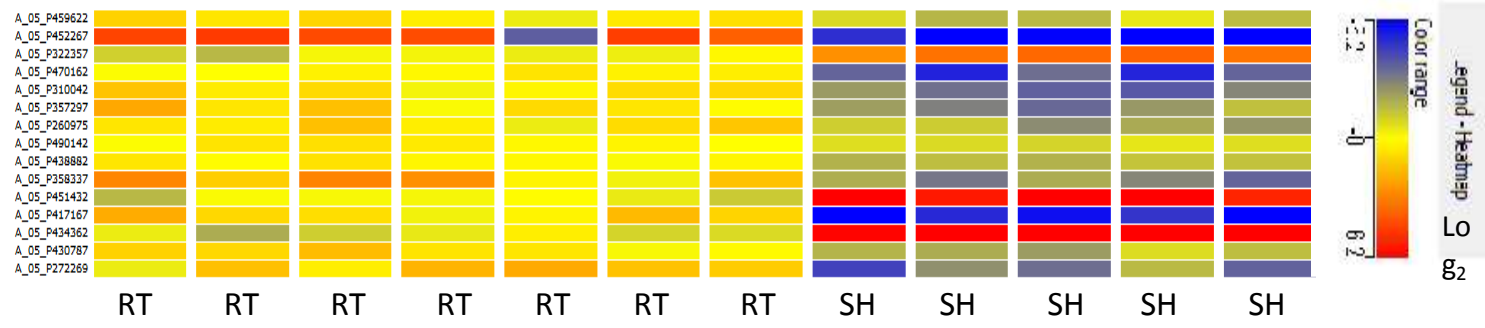

Figures 5. Heat map of gene expression for the $\mathbf{1 5}$ putative life history markers identified from the Mossy Rock Hatchery analysis.

In this heat map of expression levels for the 15 putative gene expression markers for alternative life history trajectories common to both brain (Figure 4) and gill tissues in MRHR (RT) and MRHS (SH) stocks. 


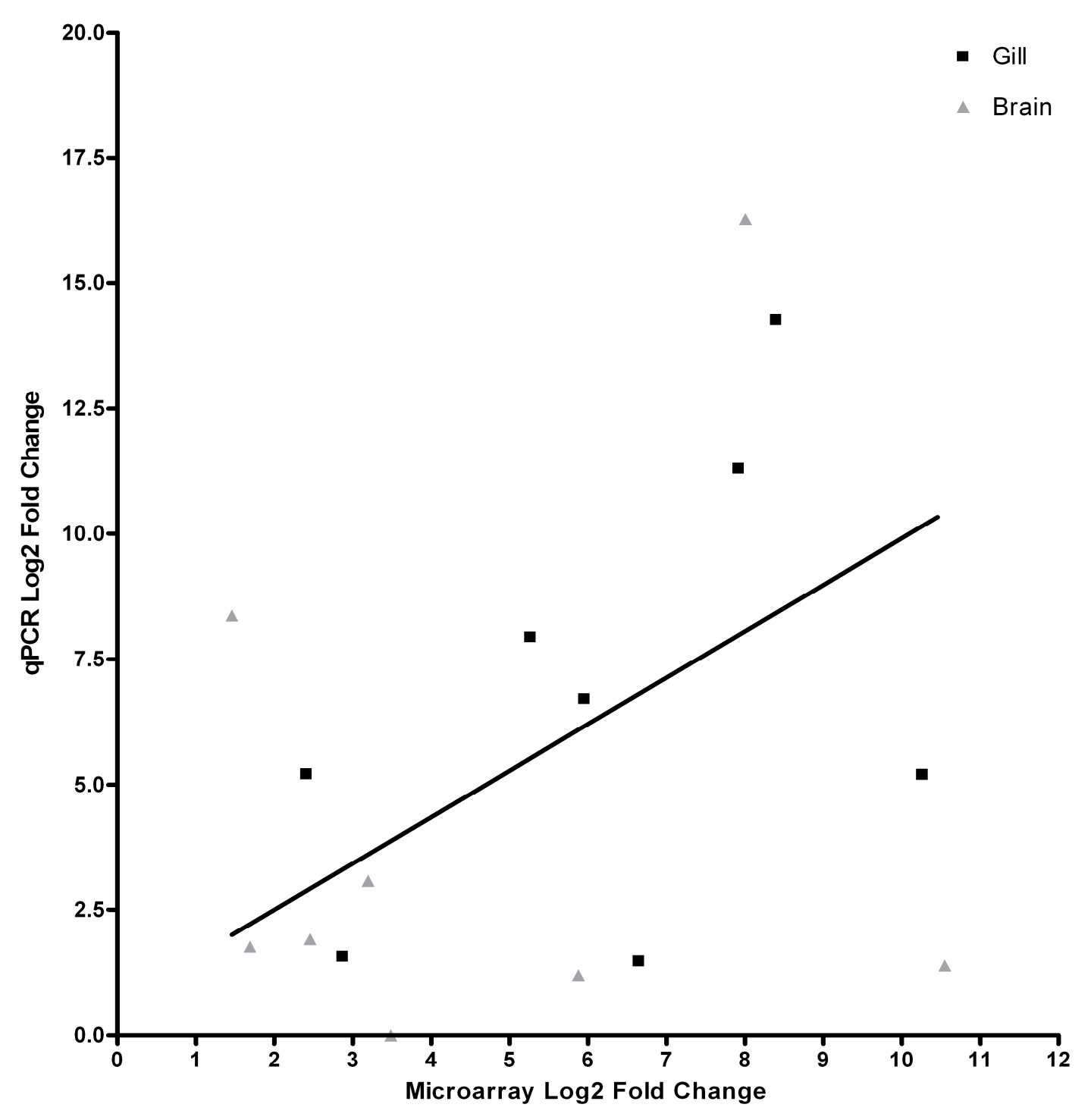

Figure 6. Graph and correlations analysis of $\mathrm{qPCR}$ and microarray gene expression data for the 8 selected life history markers.

A comparison of $\log 2$ fold change in gene expression using a microarray gene expression analysis and qPCR. A Pearson's correlation analysis was done comparing qPCR and Microarray data resulting in a significant $\mathrm{r}^{2}$ value of 0.7119

(p-value $<0.0010$ ) These data verify the validity of the microarray gene expression for the life history markers selected for all but one marker in one tissue (NM_0023714, in brain tissue). Linear regression modeling produced a slope value of $0.9263 \pm 0.2442$ and an $r^{2}$ value of 0.5069 ( $p$-value $<0.0020$ 


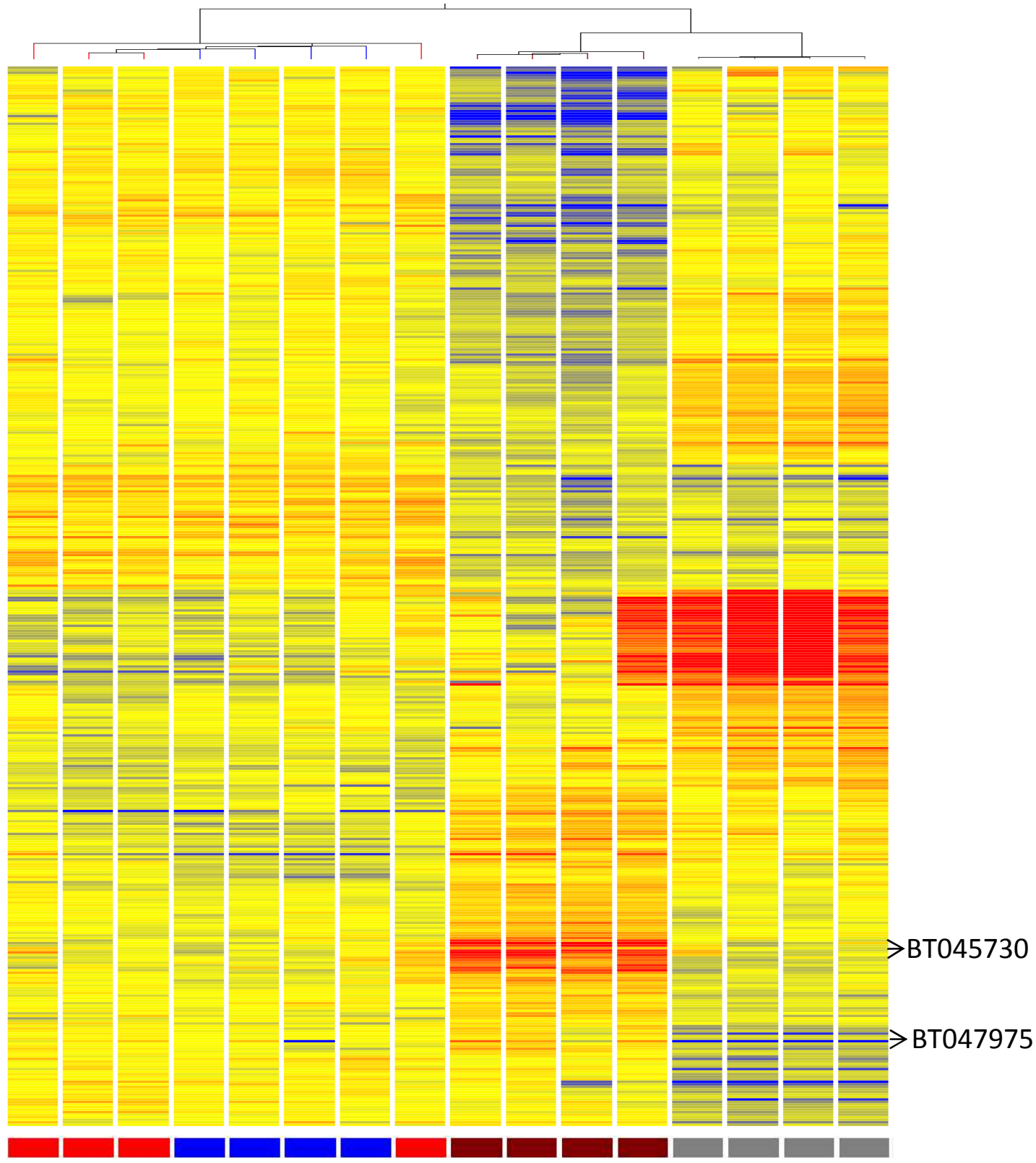

Legend - Hierarchical Combined Tree on SampletOC (Non-averaged)

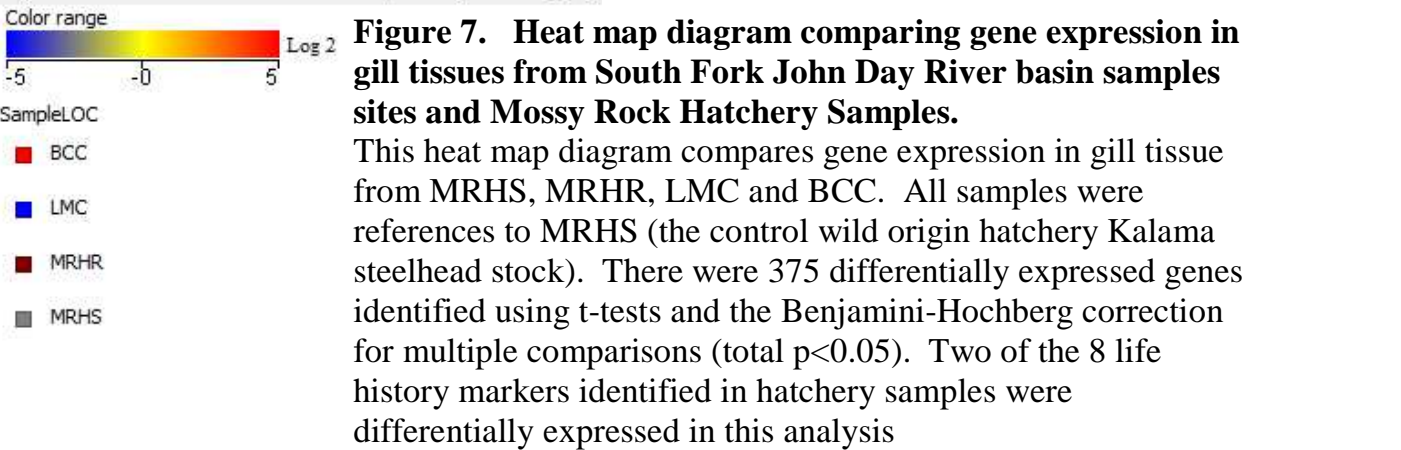




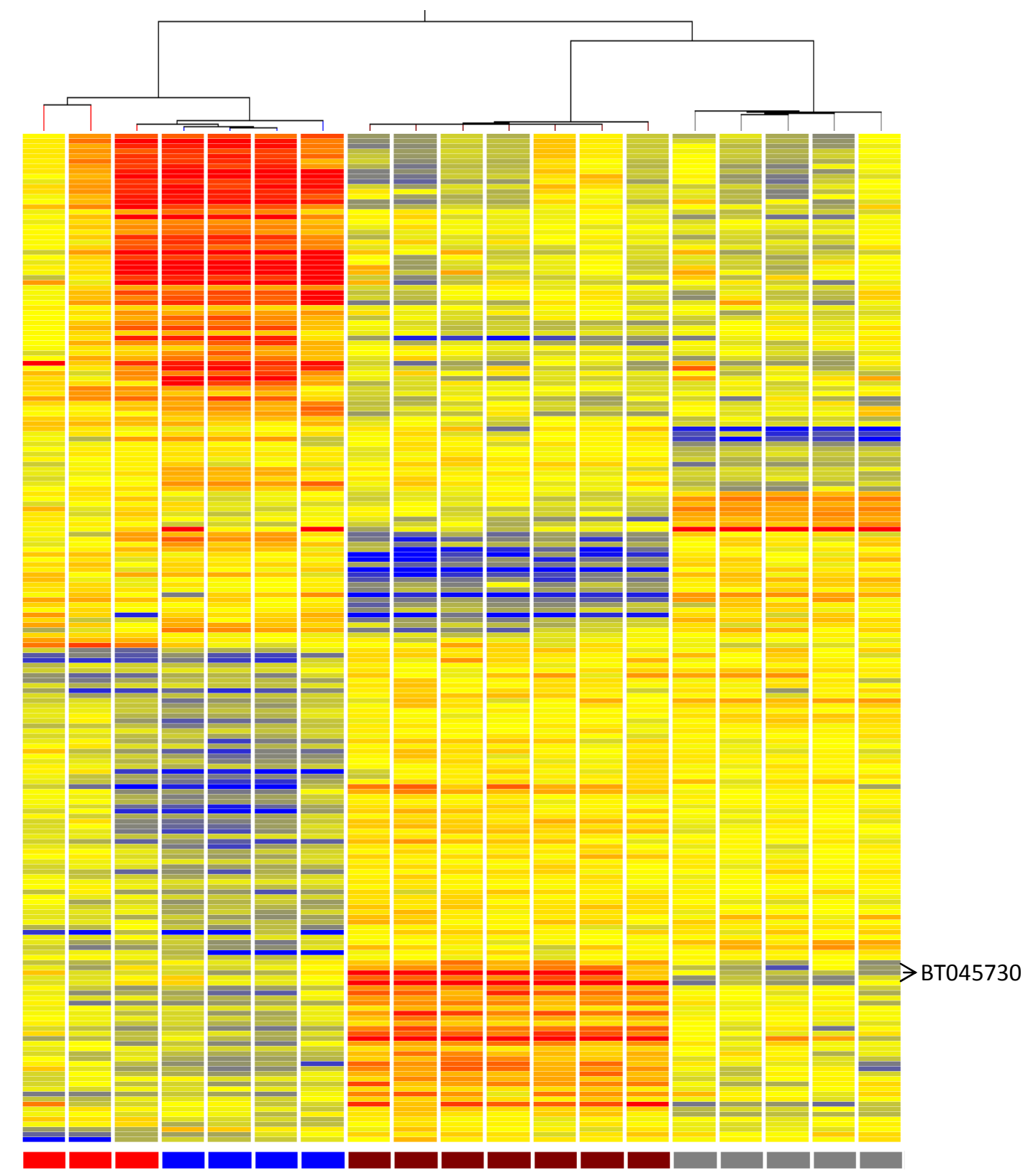

Legend - Hierarchical Combined Tree on SampleLOC (Non-averaged)

Color range

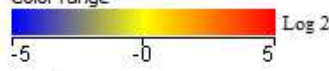

SampleLOC

- $\mathrm{BCC}$

- LMC

- MRHR

- MRHS
Figure 8. Heat map diagram comparing gene expression in brain tissues from South Fork John Day River basin samples sites and Mossy Rock Hatchery stocks. This heat map diagram compares gene expression in brain tissue from MRHS, MRHR, LMC, and BCC. All samples were references to MRHS (the control wild origin hatchery Kalama steelhead stock). There were 200 differentially expressed genes identified using t-tests and the Benjamini-Hochberg correction for multiple comparisons (total $\mathrm{p}<0.01$ ). One of the 8 life history markers identified in hatchery samples were differentially expressed in this analysis 
Figure 9. qPCR data for primer set BT045799
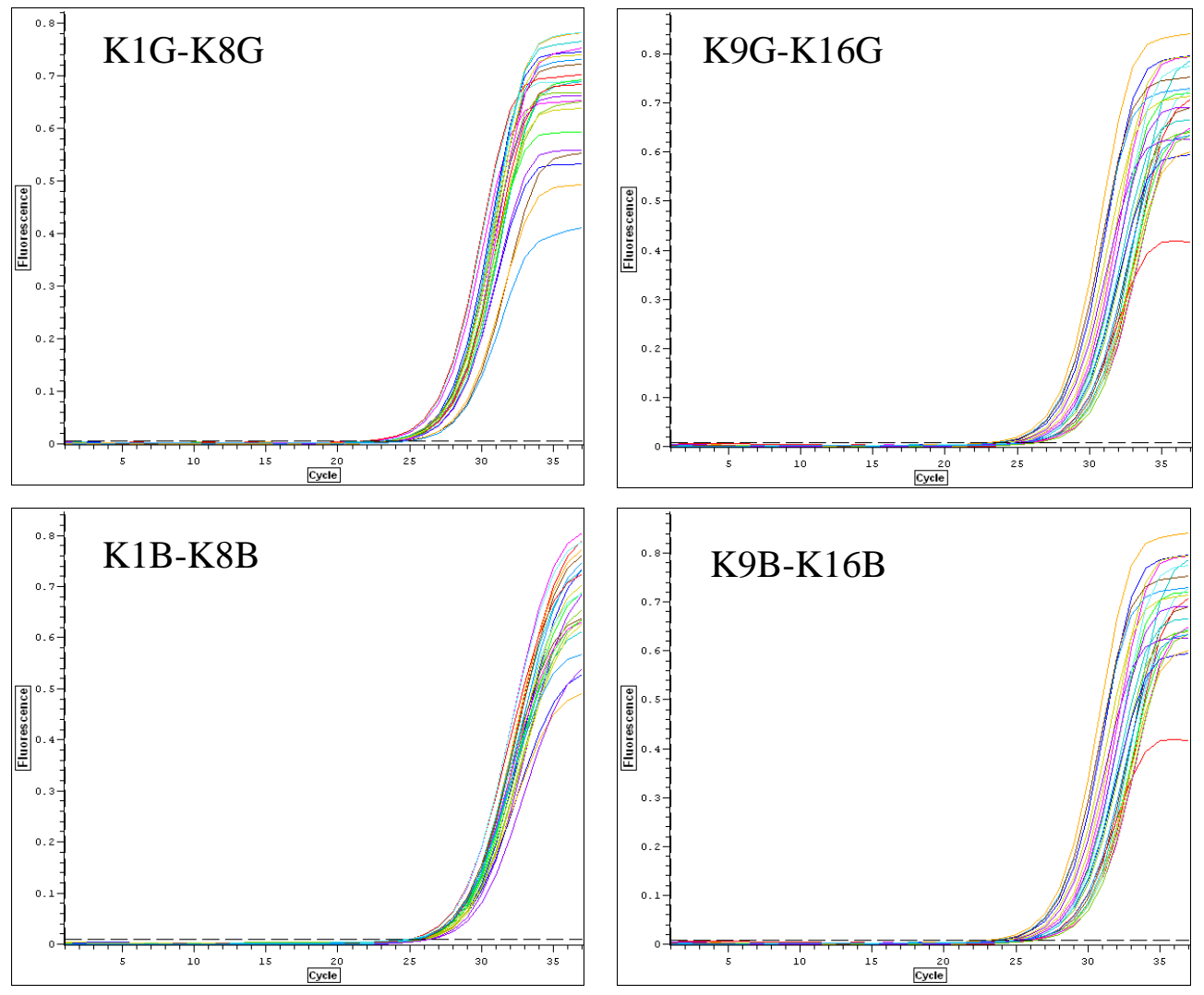
Figure 10. qPCR data for primer set BT045730
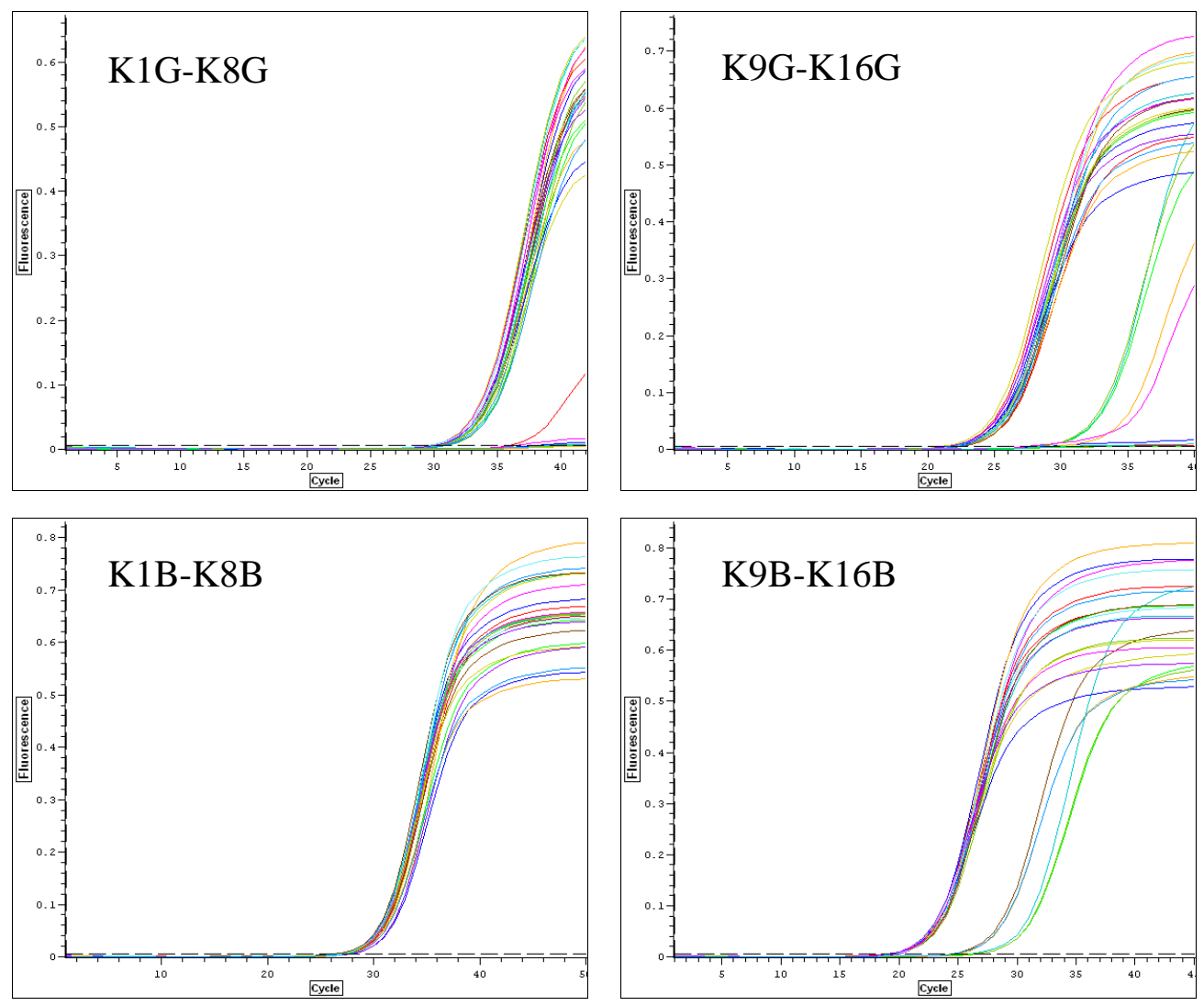
Figure 11. qPCR data for primer set BT050202
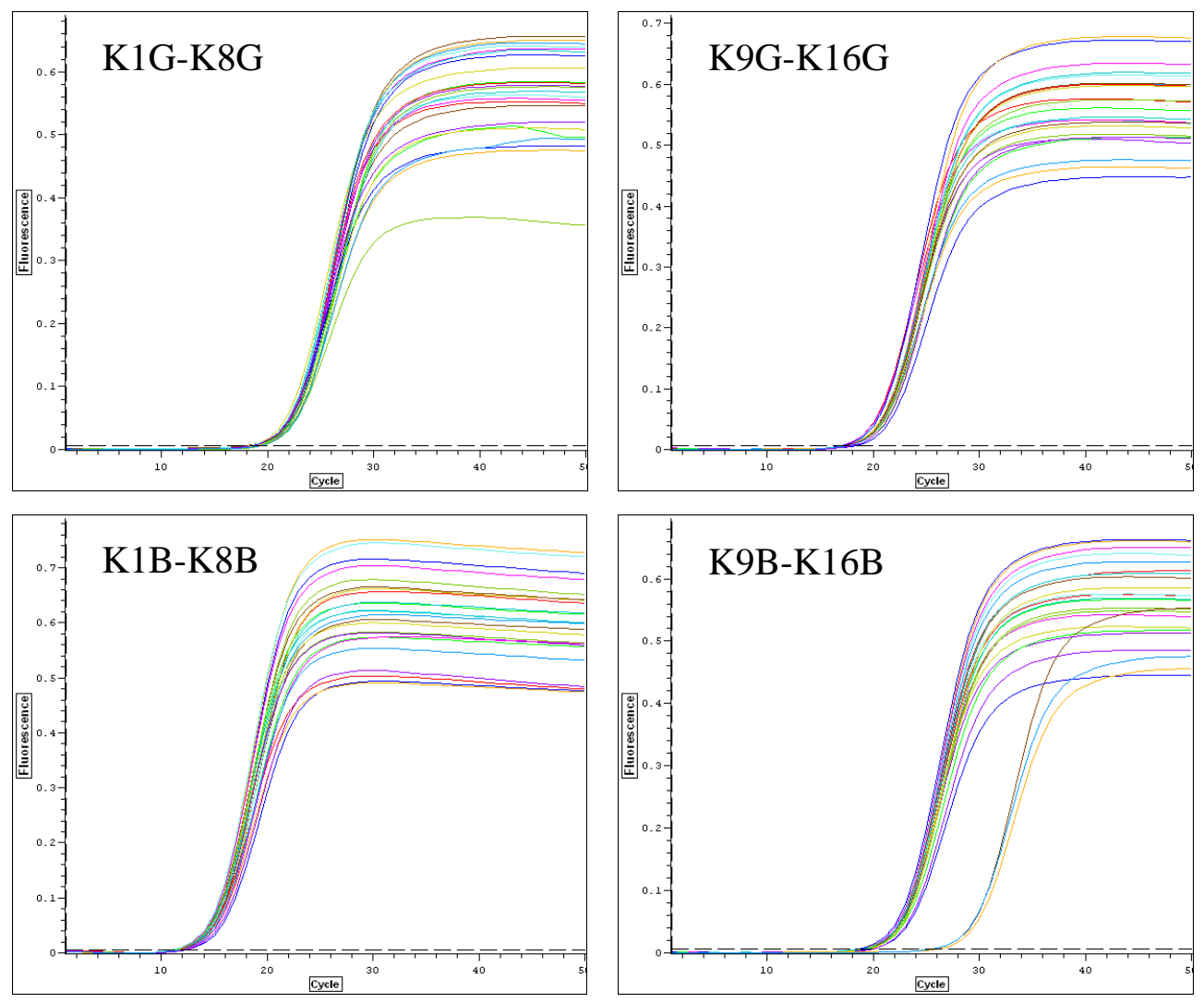
Figure 12. qPCR data for primer set EG823395
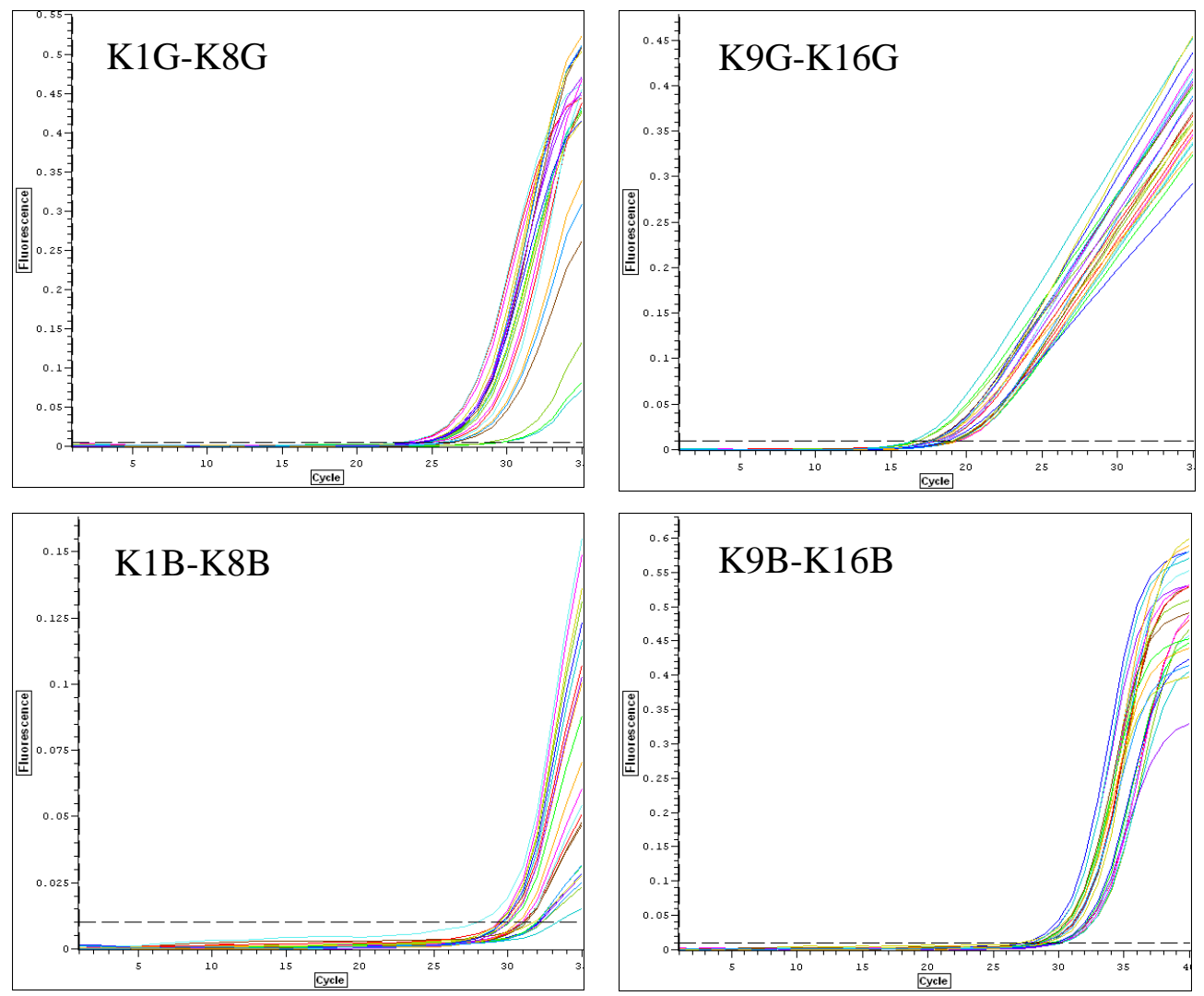
Figure 13. qPCR data for primer set BT047975
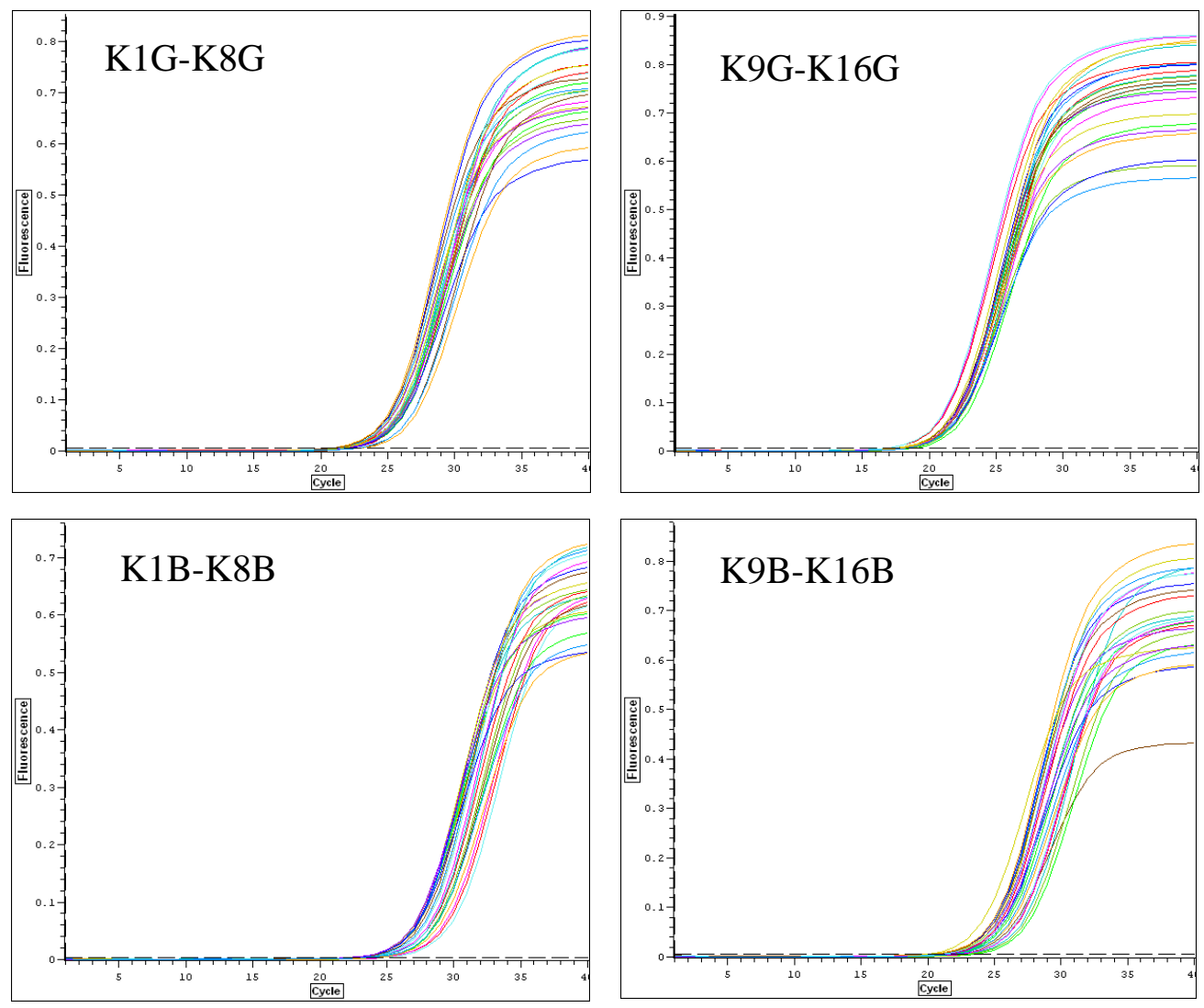
Figure 14. qPCR data for primer set $B$-Actin
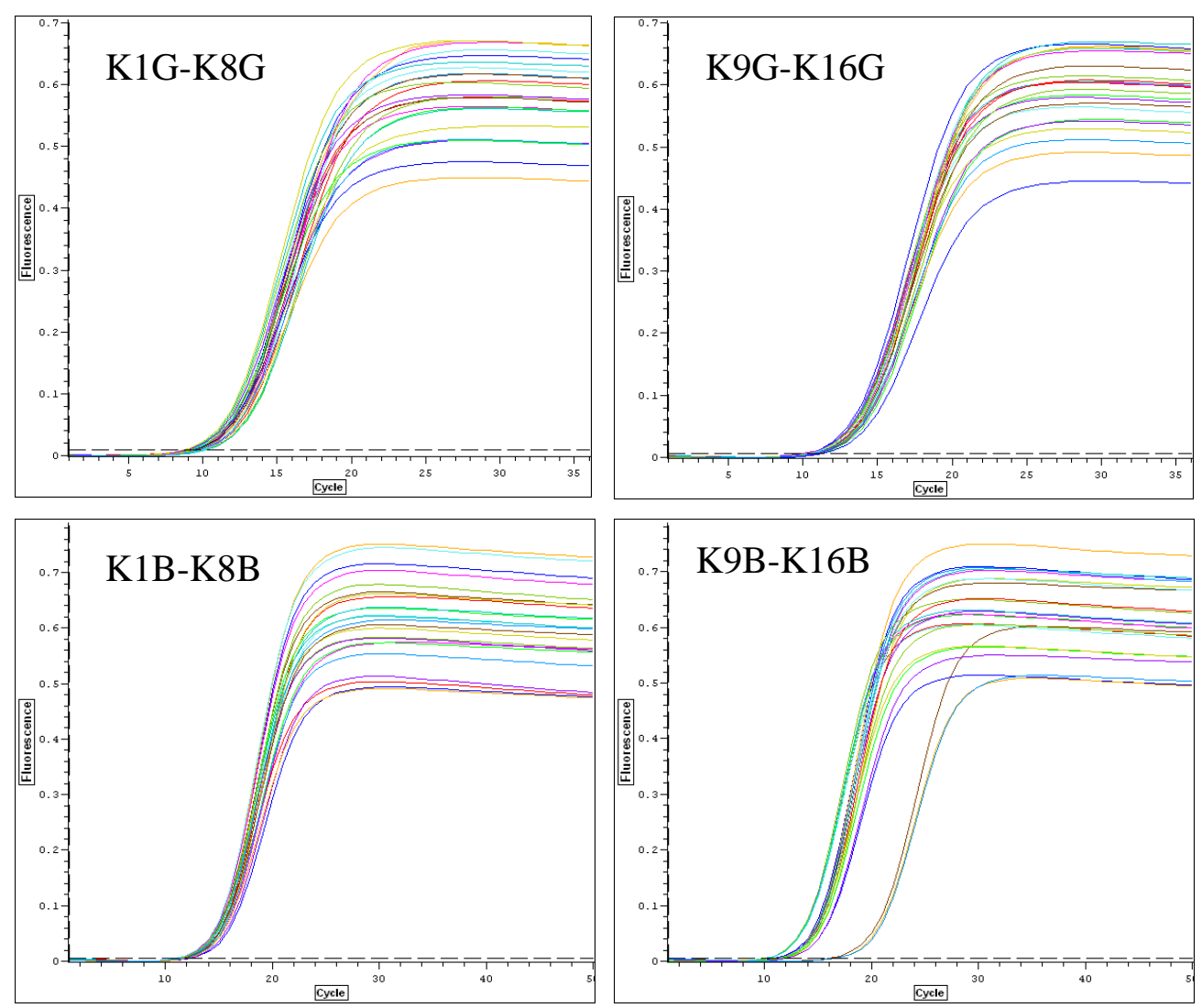
Figure 15. qPCR data for primer set BT058447
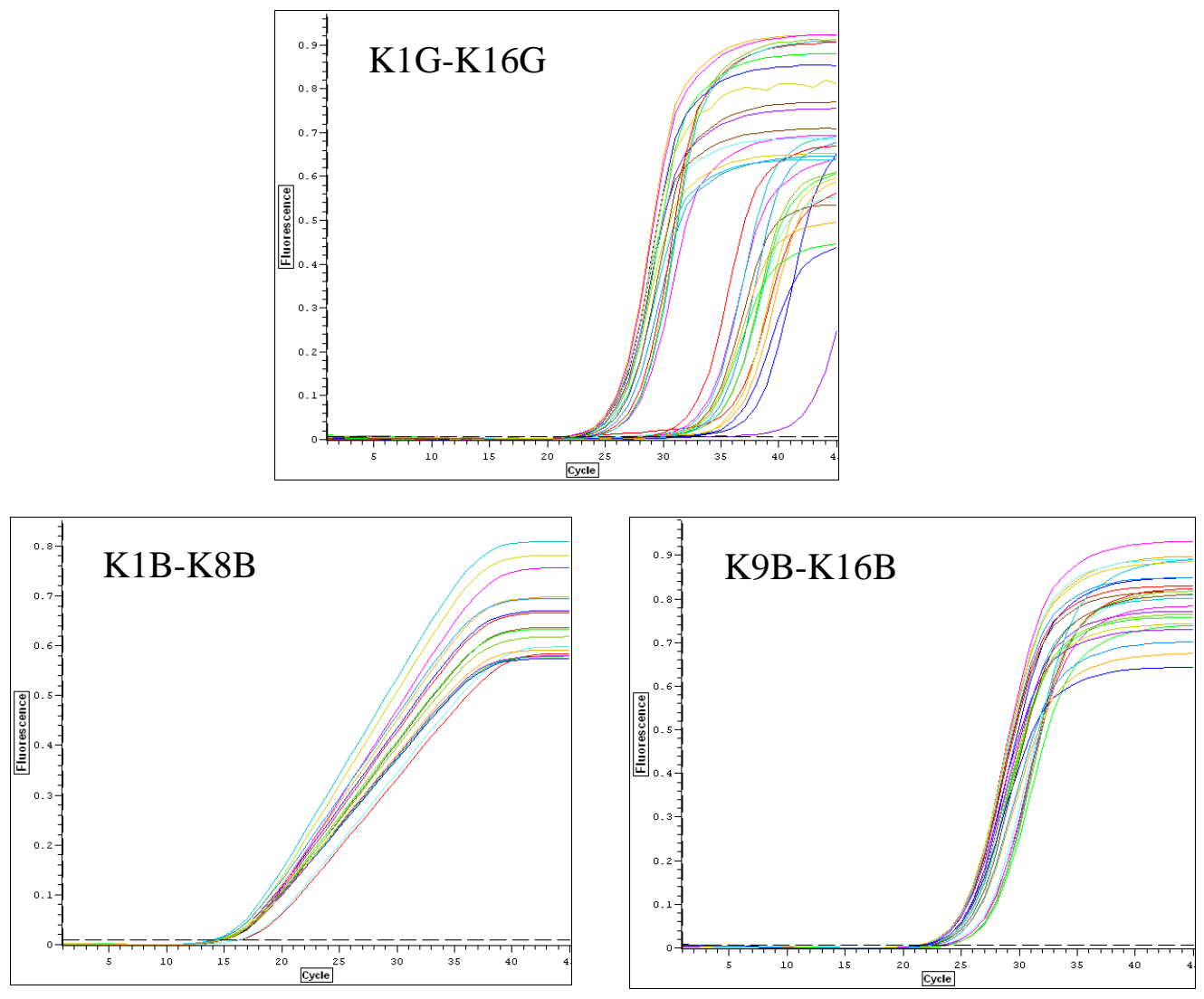
Figure 16. qPCR data for primer set NM_0023714
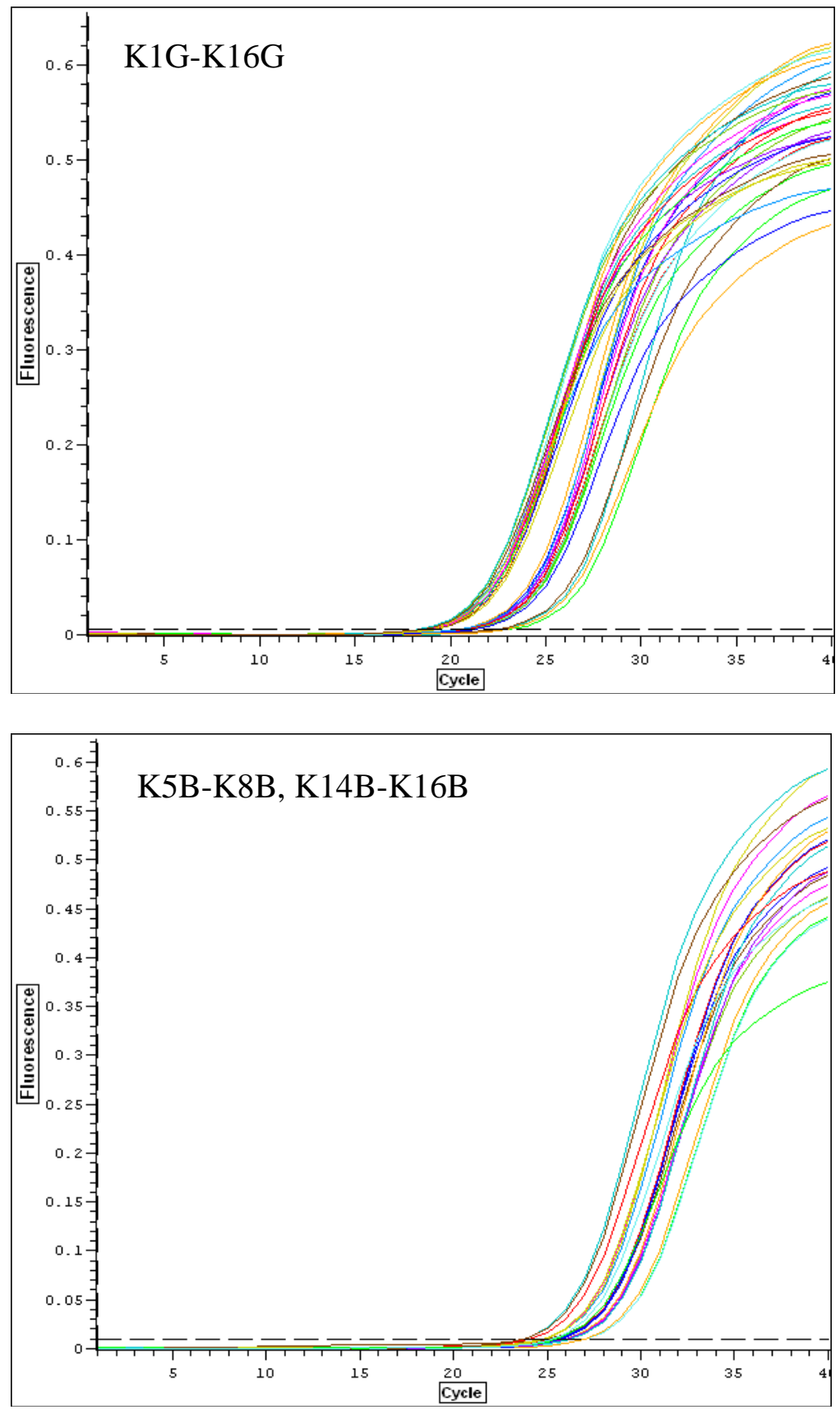
Figure 17. qPCR data for primer set NM_001141601
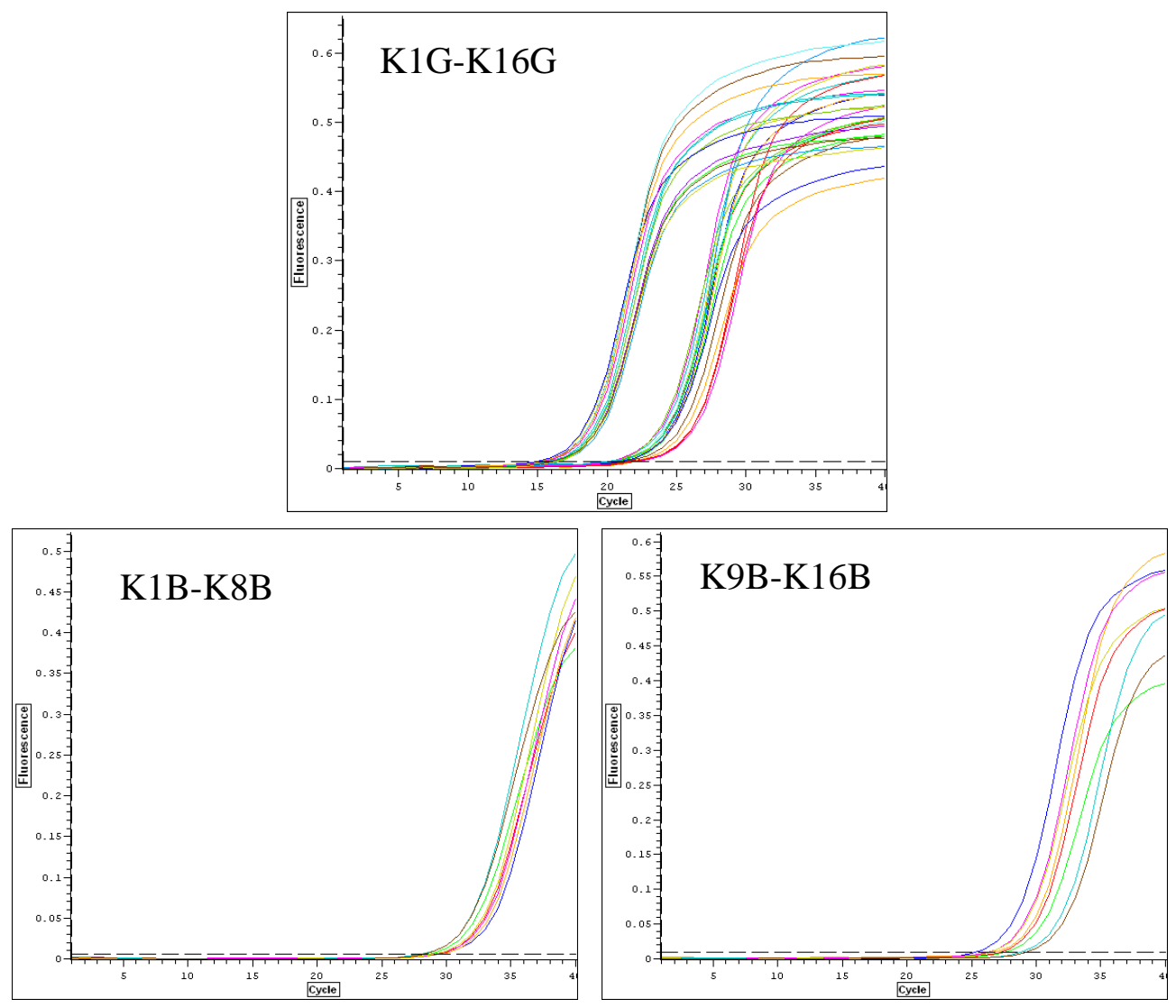


\begin{tabular}{|c|c|c|c|c|}
\hline ProbelD & PrimaryAccession & GeneSymbol & GeneName & Description \\
\hline A_05_P459622 & NM_001123714 & psmb9-b & proteasome subunit beta type & $\begin{array}{l}\text { Salmo salar proteasome subunit beta type-9b } \\
\text { (psmb9-b), mRNA [NM_001123714] }\end{array}$ \\
\hline A_05_P452267 & ВT045730 & & & $\begin{array}{l}\text { Salmo salar clone ssal-rgf-529-363 Serine } \\
\text { incorporator } 1 \text { putative mRNA, complete cds } \\
\text { [BT045730] }\end{array}$ \\
\hline A_05_P310042 & ВT058447 & & & $\begin{array}{l}\text { Salmo salar clone Contig835 Proteasome subunit } \\
\text { beta type- } 8 \text { precursor putative mRNA, complete cds } \\
\text { [BT058447] }\end{array}$ \\
\hline A_05_P357297 & EG823395 & & & $\begin{array}{l}\text { EST_ssal_evd_25036 ssalevd thymus Salmo salar } \\
\text { cDNA Salmo salar cDNA clone } \\
\text { ssal_evd_532_214_fwd 3', mRNA sequence } \\
\text { [EG823395] }\end{array}$ \\
\hline A_05_P260975 & ВT045799 & cd83 & cd83 protein & $\begin{array}{l}\text { Salmo salar clone ssal-rgf-531-267 CD83 antigen } \\
\text { precursor putative mRNA, complete cds [BT045799] }\end{array}$ \\
\hline A_05_P358337 & NM_001141601 & ddn1 & Duodenase-1 & $\begin{array}{l}\text { Salmo salar Duodenase-1 (ddn1), mRNA } \\
\text { [NM_001141601] }\end{array}$ \\
\hline A_05_P417167 & ВТ047975 & & & $\begin{array}{l}\text { Salmo salar clone ssal-eve-542-161 Proteasome } \\
\text { subunit beta type-7 precursor putative mRNA, } \\
\text { complete cds [BT047975] }\end{array}$ \\
\hline A_05_P272269 & ВТ050202 & & & $\begin{array}{l}\text { Salmo salar clone ssal-eve-515-010 Carbonyl } \\
\text { reductase } 1 \text { putative mRNA, complete cds } \\
\text { [BT050202] }\end{array}$ \\
\hline
\end{tabular}

Table 1. Eight putative life history markers identified in the Mossy Rock Hatchery gene analysis study. Of the 15 putative life history markers identified as differentially expressed in both brain and gill tissue 8 are described List of the identities and Genbank accession information for these 8 genetic markers are listed above. 
Table 2. Life history marker information: BT045730

Accession Number: BT045730

Agilent Probe ID: A_05_P452267

Gene ID: N/A

Protocol: 1: 30sec@94.0 ${ }^{\circ} \mathrm{C}$; 35: 30sec@94.0 ${ }^{\circ} \mathrm{C}, 30 \mathrm{sec} @ 68.0^{\circ} \mathrm{C}$

Primer Forward: 5-GAAGACGGCGAGAACCGGGC

Primer Reverse: 5'-TCATAGCTGGCGTCGGGGCT

Product Length: 143bp

\section{Full Sequence}

agatcgtaaa cagacgagaa gcatccatat ttcttcccgg agaagtcgta tttcagaaa acaccatggg ggccgttctt ggactgtgct ccatggcgag ttggatcccc tgcctgtgtg gcactgcccc ctgcctgctg tgcagatgct gccccagtgg gaataactcc actgtcaccc gacttatcta tgccttcttc ctccttctgg gtgtgggcat cgcatgcatc atgctaatgc cagggatgga agagcaactc aagaagattc caggattctg tgatggggga atgggtacat caatcccagg tgtggagggt catgtgaact gtgatgtctt ggtcggctac aaggctgtgt accgcgtctg ctttggcatg gccatgttct tcctgctctt ctccctcatt atggtcaagg tcaagagtag ccaggatcct agagctgcag tacacaacgg gttttggttc ttcaagtttg ctgctgcgac tgccattacc gtcggtgcat tcttcattcc agagggtgcc ttcacaactg tttggttcta cataggaatg gctggagctt tttgcttcat cctgatccag ctggtccttc tgattgactt tgcccactcc tggaatgagt cctgggtgga gaaatggag gagggcaact ctcgctgctg gtatgcagct ctgctgtctg ctacaaccat caactacatc ctgtcccttg tgtctctggt catgttctac gtctactaca cccacactga tggctgcact gagaacaagg ccttcatcac tgtcaacatg ctgctgtgtg tgggagcctc agttatgtcc atcctgccac agattcagga gtcccagcca aggtccgggt tgctgcagtc atccattgtg actctgtaca ccatgtatct cacctggtct gccatgacca atgagccaga caggaaatgc aacccaagct tgctgggtat cattggcctc aacaacacca ccccagctgg caaggaccat cctgttgttc agtggtggga tgcccagggc attgtggggc tggtcctgtt cctgatgtgt gttctatact caagcatccg caactcctcc aacacccaag tgaacaaact gactctgacc agtgatgagt ctgcactgat tgaggatggc ccccaccctg agaactttga cgtggaagac ggcgagaacc gggccgtgga caacgagaag gacggagtca cctacagcta ctccttcttc cacttcatgc tcttcctggc ctccctctac atcatgatga ccctcaccaa ctggtacagc cccgacgcca gctatgagac aatgaccagc aagtggccet ctgtgtgggt gaagatctcc tccagctgga tctgcattgc cctgtatgtg tggaccctgg ctgcaccact ggtcctggtc aatcgagact tcgactgatg agctaaagaa ttagaaggga gcgcaatcat ttgctcatga ttgtgactat tcaartgta taaggtgaac aagctctgtg tgtgtattcc ctgtggataa cccaccctt ttgtttttaa caaactgcat gcatgcaagt attgagtaca tatgtgttat ccactgtgtt ttatcctatt gcacaattta aagaatgagg attacttatg cagagttcgg gttgtaaagg tcgctggggc ttggggagat ggtcagtgga catgtggtca gttaatgaag ggagaagcac tcttcctcaa ctgtaatcgg ttctggatag gacattcaga aagaactgtt aatttgttac aaatgggta agactgctt gtttatgcta cactttcctt cactttaagt atagaggaag tgcagggttc cagatattag ctaacattat cctaggttca taagtgagca tgatttacca tttgcatgat attataggct aatctacaat catgcaaatc ttaatgttgc tgtgatttcc ttttcagaat atctgccccg attgctaacc tgcacatctt gtaatagctc aataagacc ttaagtttta tgtaccttgt gttacttatt atttgcacta gttatcttct aaggtaaa tactgatgtt caaacagtgg ataagttatt ttgtagatgc tttagcataa tttaaggtgt attaagtgtt tctagcagac aagatacatg tcagaaaatg tcaactccca tttctccaga atagtttgcc tttcgatatg tattaaagtg cattgcaaac cataaaaaa aaaaaaaa aaaaaaag a 
Table 3. Life history marker information: NM_001123714

Accession Number: NM_001123714

Agilent Probe ID: A_05_P459622

Gene Symbol: psmb9-b

Gene Name: proteasome subunit beta type- $9 \mathrm{~b}$

Protocol: 1: 30sec@94.0 ${ }^{\circ} \mathrm{C}$; 33: 30sec@94.0 ${ }^{\circ} \mathrm{C}, 30 \mathrm{sec} @ 58.0{ }^{\circ} \mathrm{C}, 30 \mathrm{sec} @ 72.0{ }^{\circ} \mathrm{C}$

Primer Forward: 5'-TGAGGCGTCGTTTGGTGTTTTCT

Primer Reverse: 5'-CTGTGCAGTCCGCACGGTGT

Product Length: 82bp

\section{Full Sequence:}

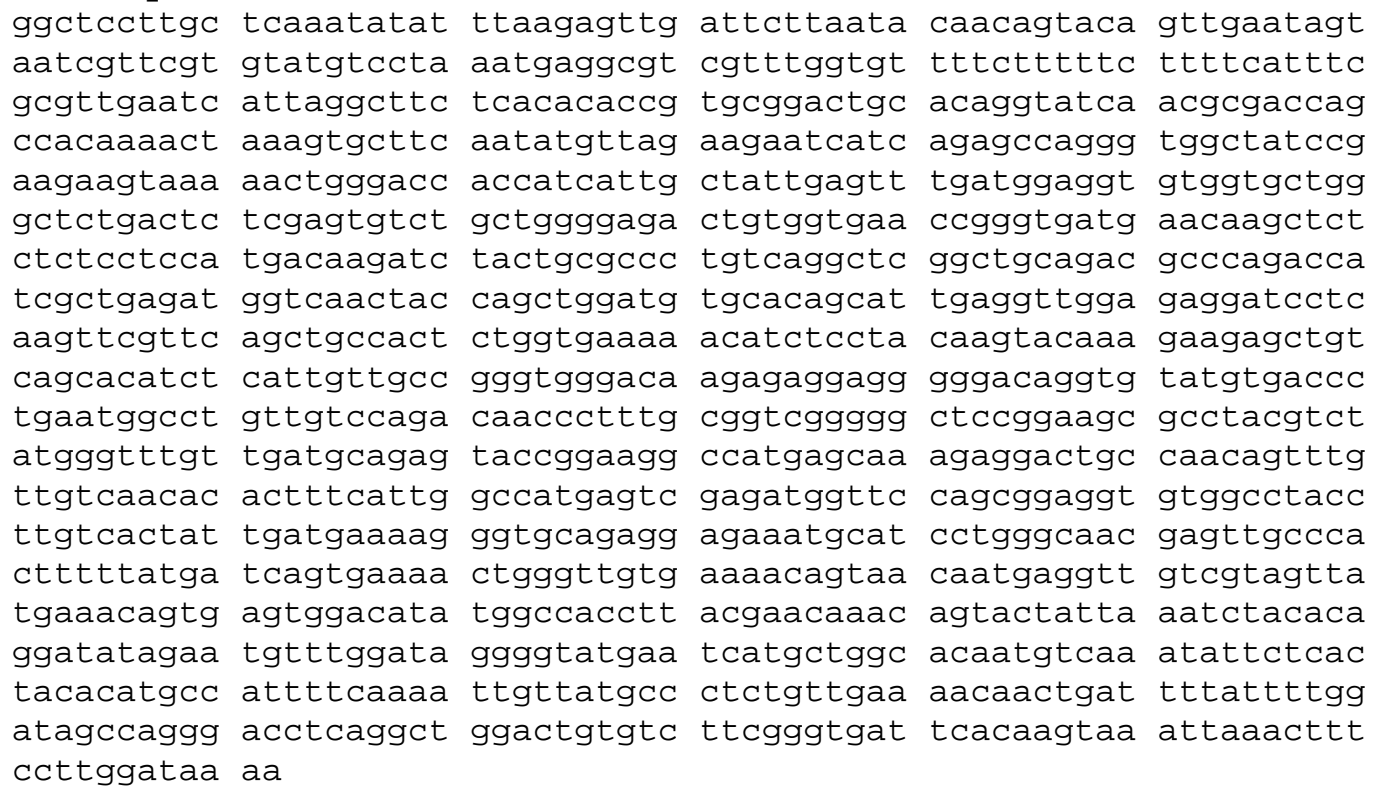


Table 4. Life history marker information: BT050202

Accession Number: BT050202

Agilent Probe ID: A_05_P272269

Gene ID: N/A

Protocol: 1: 30sec@95.0 ${ }^{\circ} \mathrm{C}$; 35: 30sec@95.0 ${ }^{\circ} \mathrm{C}, 30 \mathrm{sec} @ 68.0{ }^{\circ} \mathrm{C}$

Primer Forward: 5'-CCGCTGCAGCCCTGAACTCC

Primer Reverse: 5'-CTGCCTGGGCCTCCTGGACA

Product Length: $101 \mathrm{bp}$

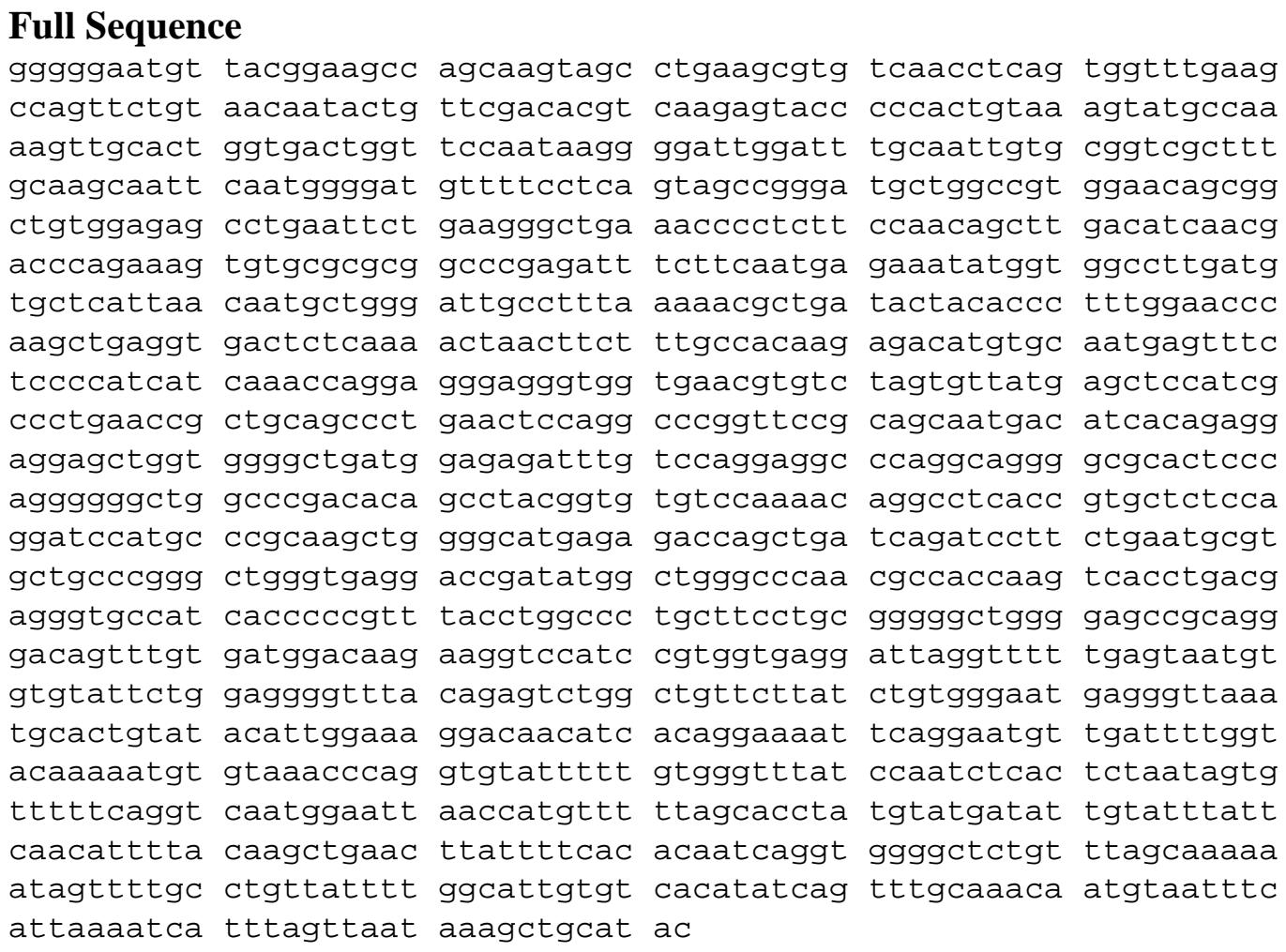


Table 5. Life history marker information: BT058447

Accession Number: BT058447

Agilent Probe ID: A_05_P310042

Gene ID: N/A

Protocol: 1: 30sec@94.0; 35: 30sec@94.0,30sec@56.0

Primer Forward: 5'-GACAGCGGCTACCGATATGA

Primer Reverse: 5'-AAAAGCGGTGGTACAGGTCG

Product Length: $181 \mathrm{bp}$

\begin{abstract}
Full Sequence
ttggccagag catctgcagg atcttacgtc agcactcaga tgtttaagaa ggtgatcgag

ataaacccct ttctacttgg gacaatgtca ggcagtgctg ccgactgtgt ctattgggag

agagtcttgg ccaaggagtg cgggatatca gattgggtta aagaggacgg attcaacgcg

gaacgagcgt cggtggataa agtcaatcac ttcaaattcg ctgctcagac accagagttg

gcggtacccg ttggagttga tccagcagag tttcttaggc ctctggttga cagtgaagaa

ggggtggatg gggtgaagat taacctggag catggcacta ctactctggc tttcaagttc

cagcatgggg tgatggtggc tgttgactcc agagcatctg caggatctta cgtcagcact

cagatgttta agaaggtgat cgagataac cccttctac ttgggacaat gtcaggcagt

gctgccgact gtgtctattg ggagagagtc ttggccaagg agtgcaggat atacaatctg

aggaacaagg agaggatctc agtatctgct gcctctaagc tccttgccaa catggtggtc

aactacagag ggatgggtct ctccatgggc acaatgatat gtggctggga caagaagggt

cctgggctgt attacgttga tgacaatggt ctgagactgt gtggaaacat gttctccact

gggtctggta acacctacgc ctatggtgtg atggacagcg gctaccgata tgacttgtct

gttccagaag cctatgattt ggcacagagg gccatctttc atgcaacaca cagagatgct

tactctgggg gaacagtcaa catgtatcac atgagagaga ctggttggat caagtttct

caagaggatg ttggcgacct gtaccaccgc ttttacaatg acaagaagtg aatctggccc

gttgtaacta tattcacagt cacatcaata ccatacaata catcatgaac atagtcaat

aagtatatca aatcataagg atcatggggc catgaccttc tctcaggcaa ccatatggca gtcactg
\end{abstract}


Table 6. Life history marker information: EG823395

Accession Number: EG823395

Agilent Probe ID: A_05_P357297

Gene ID: N/A

Protocol: 1: 30sec@94.0; 35: 30sec@94.0,30sec@57.0,30sec@72.0

Primer Forward: 5'-AAGACGGAATCTGGGAGTGG

Primer Reverse: 5'-AATGGGTCTGATGCCGTCTG

Product Length: $123 \mathrm{bp}$

\section{Full Sequence}

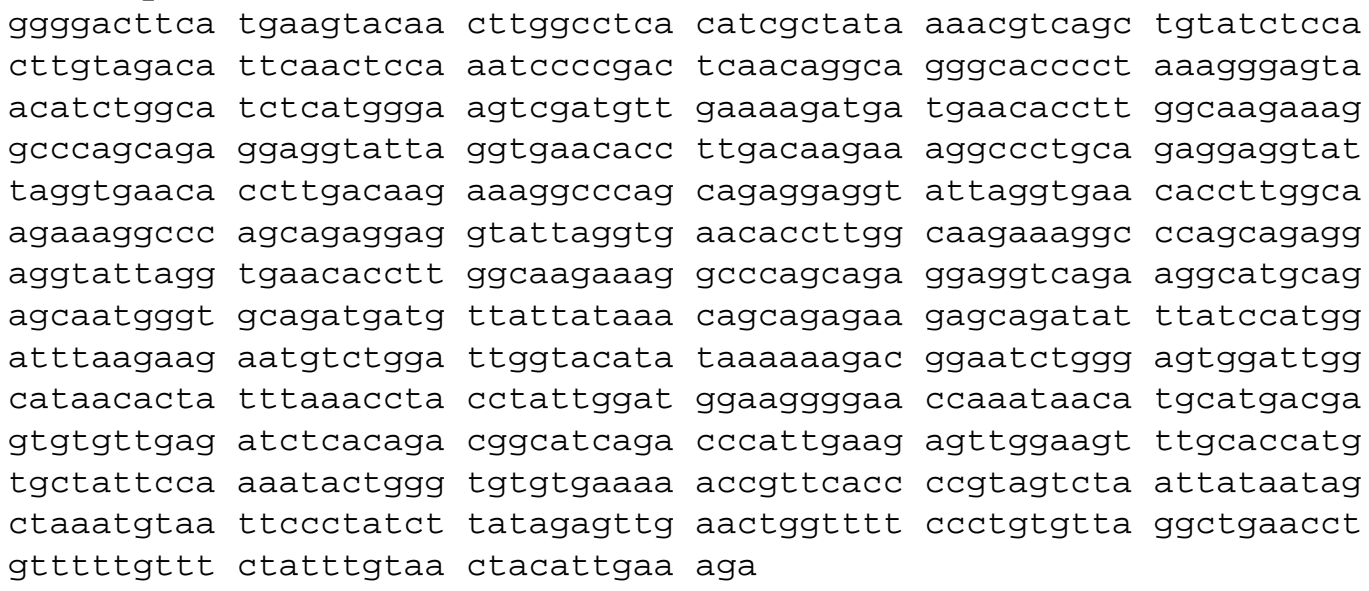


Table 7. Life history marker information: BT045799

Accession Number: BT045799

Agilent Probe ID: A_05_P260975

Gene Symbol: cd83

Gene Name: $\operatorname{cd} 83$ protein

Protocol: 1: 30sec@94.0; 30: 30sec@94.0,30sec@57.0

Primer Forward: 5'-CGTCTGCATTCTAGCTGCCT

Primer Reverse: 5'-AGCTTGTACCACCTCACTGC

Product Length: $153 \mathrm{bp}$

\begin{abstract}
Full Sequence
tctcgatcat cgtcttcatt gctgtagttc cacaaatatg tttttcaac tcgtctgcat tctagctgcc tccgtgcaat gtgggctcac acagaatatg cctacccagg aagtgaagtc aatttgtgga gaggactcaa ttctgaaatg taaagcaata tgtaagcgtg gggtccagta ccgggcagtg aggtggtaca agctaggtga ggagccctct gataaggagt ctggtctatt gatgaagagg ctatcaccta aaagcaccac cctatggtac gccggtctgg agcgggaagt ggaacttttg gctgatgatt ctttcgatat cttgctgccc aatgtaacgg ctgttgatag cgggaggtac aagtgtctcc tggcagcacc tgtaggagag cagaaccagg aggggcaggt tcacctcaga gtgacaggtt gccttgagtc tacagaccaa tcagaagaaa gggataccat cctagttctt tccattgtgg ggcttgtggc ggcattgctg atattcacca tcagctatgt catcctaagg aatatgttat tgcaaaggag taagaagtat ccacaagaac cacttctaga tgcacccct gagaagaag atgtaatgtt gatttacact ccggggccaa actggtccag acagggttcc ataaacatg tctgtgtgtg agagcctgtt ctgctcattg tatacttgaa tgtgaagagc aaatgcagag aaagactagg gcacatttga agctgagcaa cgagtctatc acgctgacca caccgcttgt gttatgtgcg tgagtgtggc aaaataaatg tacacatacc tgttattcaa caatttcatc caaactgctc gcgcgcatca acgagcgcct gcgtagcaag gctctaaat agacgcttta tgcgctgcaa gtccactttc tcccatctcc tcattgggtt ttcagagcat atacccacat gggtgattga agatgaact gcgatccaca ctctagccca gttggtggtg gtaatgcacc ttaaagttgg ttgtcaaacg ccatataaag tcagaagaag actgacggag gagagattac tagaaacaaa ctaagtttac cctttatct gtggattaat tgtcagagta gaggaccttg tgtatttcag gtaaaataac aacccaatac ttatactttc caggagaaga gttcaccact agagcagatg gaggcagaca accctctggg ttagaactaa gatgtttagg cttttcaaag aaatgaaaca gaaacagtag cctacaccgt ttcactcagg cagtcaaaca gcagtacaaa gtcaggctag aacagcagtt ctccagcaat gattgctcgt ctgcagcatt cacacgcctg tgatgcgcaa gcagcagggc ctggtgaagg gacccacaat ctaagcccca agatctaacc tcaataagga gcttcaggaa ggggtgcagg aatggcctac gatgaggggt cattctggag ggttgctcca tggcaacgtg ggggttaata tcatttacat ttgagtcaac ccagaattga agtcgacatt gactttgaac tgggaaatga cccatgtgta cagaactgat ctttragat tgcctaattc aattcctgta ctgactggta ttgaataaa attgattcaa ttgcctccaa gcaaatgaa agtgggcttt ggtgaaaagt aattggcaga aatctatca ggtttt aaa atattatcag caattctgtg gacacattga aataagaa gccttgtaaa taaaaaaaa aaaaaaaaa aaaaaaaaa aaaaaaaaa ga
\end{abstract}


Table 8. Life history marker information: NM_001141601

Accession Number: NM_001141601

Agilent Probe ID: A_05_P358337

Gene Symbol: ddn 1

Gene Name: Duodenase-1

Protocol: 1: 30sec@94.0; 33: 30sec@94.0,30sec@58.0,30sec@72.0

Primer Forward: 5'-TGCCTTGCTGCTGGATGGGG

Primer Reverse: 5'-TCCCACTGCTTCTGGCAGACC

Product Length: $110 \mathrm{bp}$

Full Sequence:

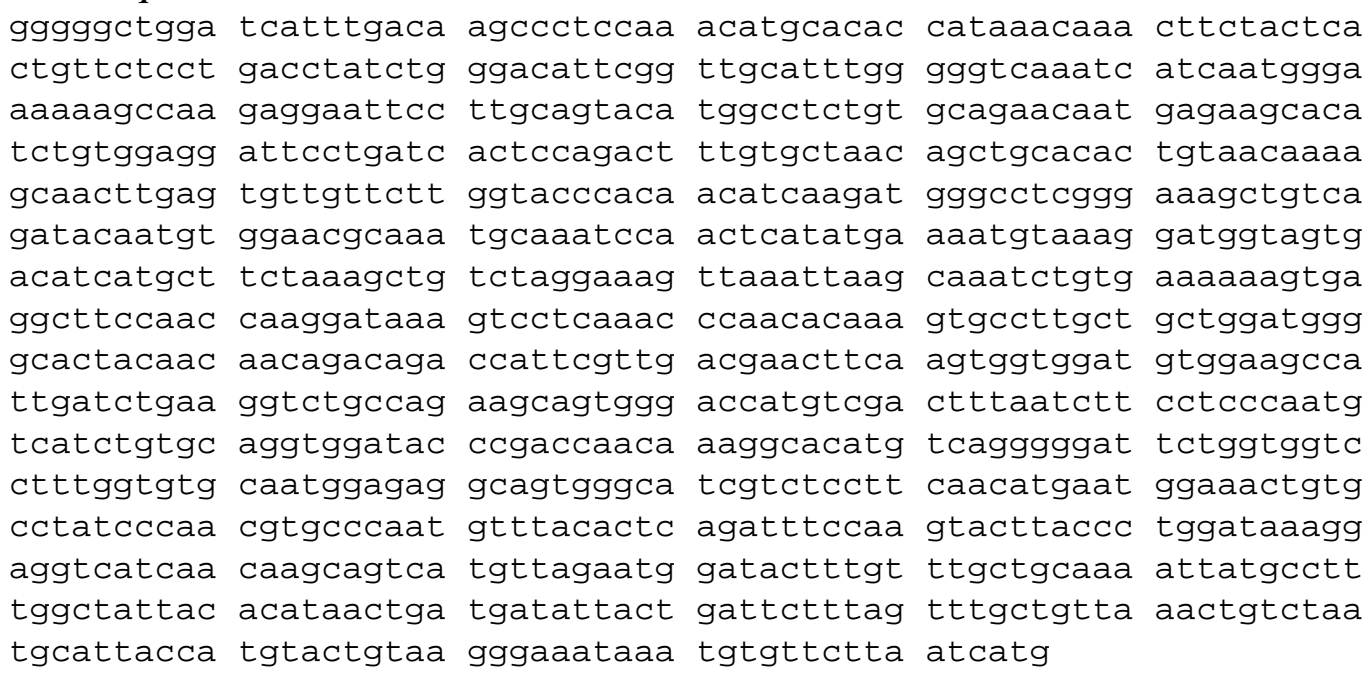


Table 9. Life history marker information: BT047975

Accession Number: BT047975

Agilent Probe ID: A_05_P417167

Gene Symbol: N/A

Gene Name: N/A

Protocol: 1: 30sec@94.0; 40: 30sec@94.0,30sec@58.0

Primer Forward: 5'-ACGTGTCGTGATGGCAGTAA

Primer Reverse: 5'-AATCCCCAAAGCAGCCAAGT

Product Length: 190bp

\section{Full Sequence}

gggggagatc gagaatattg cgacctcgtg cgacgtgcaa agggttgtag ggaagtcaga
atcttacaat tgagtgcaaa ataaccctt tcaggtatgg cgctatcaa tgttctcgaa
atacctacat cgggatttaa tttcaagaac gtcgccagaa atgttgctct ggagggcctg
cttgagggag gacataccaa gacacttaag cctatgaaga ctgggaccac catagctgga
ctagtgtgca aggagggagt ggtactggga gcagacacgc gggccacctc cggtgaagtg
gtggctgata agatgtgtgc caagatccac tacatctcc ccatatata ctgctgtggt
gcagggactg cagcggatac agagaagacc accgacctgc tctcctccaa cctcaccatc
ttttctatga acagcggcag gaacccacgt gtcgtgatgg cagtaaacat actgcaggac
atgctattca ggtaccgggg ccagataggg gccagtctaa tcctaggagg ggtggactgt
accggtaatc acctctacac agtggggccc tatgggagca tagacaatgt gcaatacctt
gcaatggggt ctggcgactt ggctgctttg gggattctgg aggacaggtt caaacctaat
atggagatgg aggaggctaa ggagctggtc cgggatgcca tccactctgg catcatgagt
gacctgggct caggaaacaa catagatatc tgtgtcatca ctaaacaggg ggtggactac
atcaggccgt accaggagtc agagtacaaa gacaagaggc ggaagagata caagtatggc
acaggtacaa cgtctatttt gacagagaaa atagtccctc tggagctgga ggtggtgcag
aagacagtcc agcggatgga tactgcctga acctgaccac tctgaaacga cagagaggct
ggagacagtc acacagaggc taatcacaat attcagacat aaaataaatg aatacaagac
acctgataat gacaagactt gactactagg tgacactaca atgcaaagcc ataaaatcat
tgtgacataa agatcttagt tgaatgaact gtagtcagcg atacattttg aacaggtaat
aggcctaggc tagtgggtga aatattgtaa agtgattgat tgaataaaaa gtctacattc tt




\begin{tabular}{|c|c|c|c|c|c|c|c|c|c|}
\hline$C_{t}$ VALUE BRAIN & Beta-Actin & ВТ045799 & ВT050202 & ВТ058447 & NM_001141601 & ВТ047975 & NM_0023714 & ВT045730 & EG823395 \\
\hline K1 & 11.43 & 25.49 & 21.38 & 15.70 & 29.36 & 23.83 & 27.25 & 27.22 & 25.10 \\
\hline K2 & 11.03 & 25.27 & 20.46 & 14.08 & 28.74 & 22.14 & 25.95 & 26.97 & 23.46 \\
\hline K3 & 10.99 & 26.22 & 20.83 & 14.11 & 29.47 & 22.27 & 27.55 & 27.09 & 27.28 \\
\hline K4 & 10.99 & 25.45 & 15.90 & 13.93 & 29.60 & 22.26 & 27.24 & 27.14 & 26.54 \\
\hline K5 & 11.02 & 25.05 & 21.10 & 14.28 & 29.24 & 23.20 & 23.93 & 27.22 & 24.70 \\
\hline K6 & 11.24 & 25.69 & 20.55 & 13.80 & 28.16 & 23.66 & 26.12 & 27.35 & 28.54 \\
\hline K7 & 11.84 & 26.11 & 20.98 & 14.06 & 29.09 & 22.47 & 25.08 & 27.96 & 27.23 \\
\hline K8 & 11.25 & 25.54 & 20.74 & 14.32 & 28.32 & 23.71 & 25.13 & 27.60 & 25.48 \\
\hline K9 & 11.22 & 19.23 & 22.05 & 12.75 & 26.30 & 22.60 & 27.08 & 17.77 & 26.06 \\
\hline K10 & 11.45 & 19.27 & 21.07 & 12.15 & 26.60 & 21.74 & 26.16 & 17.98 & 25.77 \\
\hline K11 & 11.11 & 17.79 & 20.05 & 11.90 & 24.44 & 20.79 & 26.45 & 17.97 & 24.37 \\
\hline K12 & 11.21 & 19.29 & 20.34 & 11.50 & 25.25 & 20.72 & 28.29 & 17.89 & 25.50 \\
\hline K13 & 11.34 & 18.35 & 21.24 & 11.76 & 25.30 & 21.23 & - & 18.11 & 24.93 \\
\hline K14 & 11.23 & 16.68 & 21.74 & 13.12 & 28.12 & 23.26 & 23.90 & 24.17 & 25.10 \\
\hline K15 & 11.83 & 18.24 & 21.18 & 11.57 & 25.53 & 21.36 & 22.94 & 17.89 & 25.58 \\
\hline K16 & 11.34 & 17.67 & 21.63 & 12.19 & 28.58 & 22.25 & 24.28 & 23.13 & 25.99 \\
\hline \multicolumn{10}{|l|}{$C_{\mathrm{t}}$ VALUE Gill } \\
\hline K1 & 11.57 & 22.43 & 18.56 & 23.69 & 19.59 & 21.79 & 21.05 & 30.02 & 22.43 \\
\hline K2 & 12.11 & 23.68 & 19.11 & 27.28 & 19.69 & 22.06 & 21.17 & 30.69 & 23.68 \\
\hline K3 & 11.72 & 23.54 & 18.80 & 30.79 & 24.40 & 21.36 & 20.68 & 30.34 & 23.54 \\
\hline K4 & 11.92 & 23.08 & 18.47 & 29.23 & 19.50 & 21.23 & 20.68 & 30.35 & 23.08 \\
\hline K5 & 11.68 & 23.69 & 18.49 & 28.62 & 20.08 & 22.22 & 20.83 & 29.71 & 23.69 \\
\hline K6 & 11.49 & 23.50 & 18.86 & 29.63 & 19.30 & 22.11 & 22.95 & 30.07 & 23.50 \\
\hline K7 & 11.65 & 24.04 & 18.45 & 31.26 & 19.63 & 22.08 & 21.06 & 29.96 & 24.04 \\
\hline K8 & 12.25 & 24.86 & 19.06 & 29.52 & 20.61 & 23.02 & 22.68 & 30.47 & 24.86 \\
\hline K9 & 10.25 & 22.43 & 16.89 & 23.53 & 21.16 & 18.34 & 18.85 & - & 24.39 \\
\hline K10 & 10.14 & 23.68 & 17.24 & 22.28 & 14.73 & 18.05 & 18.87 & - & 24.60 \\
\hline K11 & 10.15 & 23.54 & 17.21 & 21.97 & 13.79 & 17.98 & 19.17 & 11.43 & 22.86 \\
\hline K12 & 10.67 & 23.08 & 17.45 & 21.56 & 14.00 & 17.79 & 19.04 & 11.54 & 24.50 \\
\hline K13 & 10.53 & 23.69 & 17.43 & 21.66 & 14.26 & 16.91 & 18.88 & 11.72 & 23.57 \\
\hline K14 & 10.92 & 23.50 & 17.71 & 23.71 & 14.82 & 18.41 & 18.39 & 11.62 & 21.92 \\
\hline K15 & 10.92 & 24.04 & 17.97 & 22.00 & 15.09 & 17.92 & 18.75 & 12.19 & 23.48 \\
\hline K16 & 10.64 & 24.86 & 17.45 & 22.98 & 15.08 & 18.02 & 18.58 & 16.66 & 22.93 \\
\hline
\end{tabular}

Table 10. Average $\mathbf{C t}$ values for the $\mathbf{8}$ life history markers identified in this study for the Mossy Rock Hatchery samples. This table contains the average $C_{t}$ values for the 8 life history markers identified in the Mossy Rock Hatchery Steelhead (MRHS) and Mossy Rock Hatchery Rainbow Trout(MRHR) compiled from qPCR data for the 8 life history markers. 


\section{REFERENCES}

Allendorf, F. W., and G. H. Thorgaard, 1984, Tetraploidy and the Evolution of Salmonid Fishes, in B. J. Turner, ed., Evolutionary Genetics of Fishes: Monographs in Evolutionary Biology: Washington, Springer US.

Aubin-Horth, N., C. R. Landry, B. H. Letcher, and H. A. Hofmann, 2005, Alternative life histories shape brain gene expression profiles in males of the same population: Proceedings of the Royal Society B: Biological Sciences, v. 272, p. 1655-1662.

Beckman, B. R., D. A. Larsen, B. L. Pewalk, and W. W. Dickhoff, 1998, Relation of Fish Size and Growth Rate to Migration of Spring Chinook Salmon Smolts: North American Journal of Fisheries Management, v. 18, p. 537-546.

Brown, K. H., D. E. Robert, R. E. Weber, and G. Thorgaard, H., 2006, Intraspecific variation in the rainbow trout mitochondrial DNA genome: Comparative Biochemistry and Physiology, v. D1, p. 219-226.

Carmichael, R. W., and B. J. Talyor, 2010, Conservation and Recovery Plan for Oregon Steelhead Populations in the Middle Columbia River Steelhead Distict Populations Segment, Oregon Department of Fish and Wildlife.

Chen, L., Y. Zhu, G. Zhang, C. Gao, W. Zhong, and X. Zhang, 2011, CD83-stimulated monocytes suppress T-cell immune responses through production of prostaglandin E2.: Proc Natl Acad Sci USA, v. 108, p. 18778-18783.

Chilcote, M. W., 2003, The relationship between natural productivity and the frequency of wild fish in mixed spawning populations of wild and hatchery steelhead (Oncorhynchus mykiss), v. 60, p. 1057-1067.

Chilcote, M. W., S. A. Leider, and J. J. Loch, 1986, Differential Reproductive Success of Hatchery and Wild Summer-Run Steelhead under Natural Conditions: Transactions of the American Fisheries Society, v. 115, p. 726-735.

Christie, M. R., M. L. Marine, and M. S. Blouin, 2011, Who are the missing parents? Grandparentage analysis identifies multiple sources of gene flow into a wild population.: Molecular Ecology, v. 20, p. 1263-1276. 
Devlin, R. H., 1993, Sequence of sockeye salmon type 1 and 2 growth hormone genes and the relationship of rainbow trout with Atlantic and Pacific salmon: Canadian Journal of Fisheries and Aquatic Sciences, v. 50, p. 1738-1748.

Docker, M. F., and D. D. Heath, 2003, Genetic comparison between sympatric anadromous steelhead and freshwater resident rainbow trout in British Columbia, Canada: Conservation Genetics, v. 4, p. 227-231.

Doucett, R. R., W. Hooper, and G. Power, 1999, Identification of anadromous and nonanadromous brook trout and their progeny in the Tabusintac River, New Brunswick, by means of multiple-stable-isotope analysis. : Transactions of the American Fisheries Society, v. 128, p. 278-288.

Evans, J. D., and D. E. Wheeler, 2001, Gene Expression and evolution of insect polyphenisms: BioEssays, v. 23, p. 62-68.

Good, T. P., and R. S. Waples, Steelhead: Background and History of Listing, NOAA Northwest Fisheries Center.

Gresh, T., J. Lichatowich, and P. Schoonmaker, 2000, An Estimation of Historic and Current Levels of Salmon Production in the Northeast Pacific Ecosystems: Evidence of a Nutrient Deficit in the Freshwater Systems of the Pacific Northwest: Fisheries, v. 25, p. 15-21.

Gross, M. R., R. M. Coleman, and R. M. McDowall, 1988, Aquatic productivity and the evolution of diadromous fish migration: Science, v. 239, p. 1291-1293.

Helfield, J. M., and R. J. Niaman, 2001, Effects of Salmon-Derived Nitrogen on Riparian Forest Growth and Implications for Stream Productivity: Ecology, v. 82, p. 24032409.

Hendry, A. P., and S. C. Stearns, 2003, Evolution Illuminated: Salmon and Their Relatives, New York, NY, Oxford University Press.

Hoar, W., S., 1976, Smolt Transformation: Evolution, Behavior, and Physiology, v. 33, p. 1233-1252. 
Holtby, B. L., B. C. Andersen, and R. K. Kadowaki, 1990, Importance of Smolt Size and Early Ocean Growth in Interannual Variability in Marine Survival of Coho Salmon (Oncorhynchus kisutch): Canadian Journal of Fisheries and Aquatic Sciences, v. 47, p. 2181-2194.

Hutchings, J. A., and M. E. B. Jones, 1998, Life History variation and growth rate thresholds for maturity in Atlantic salmon, Salmo Salar: Canadian Journal of Fisheries and Aquatic Sciences, v. 55, p. 22-47.

Jonsson, R., and N. Jonsson, 1993, Partial Migration: niche shift versus sexual maturation in fishes: Reviews in Fish Biology and Fisheries, v. 3, p. 348-365.

Kinunen, W., and J. R. Moring, 1976, Status and Origin of Rainbow Trout Brood Stocks in Oregon, Oregon Department of Fish and Wildlife.

Kutty, M. N., and R. L. Saunders, 1973, Swimming Performance of Young Atlantic Salmon (Salmo salar) as Affected by Reduced Ambient Oxygen Concentration.: Journal of the Fisheries Research Board of Canada, v. 30, p. 223-227.

McMichael, G. A., C. S. Sharpe, and T. N. Pearsons, 1997, Effects of Residual HatcheryReared Steelhead on Growth of Wild Rainbow Trout and Spring Chinook Salmon, v. 126, p. 230-239.

McPhail, J. D., 1997, The Origin and Speciation of Oncorhynchus Revisited: New York, New York.

Metcalfe, N. B., N. H. C. Fraser, and M. D. Burns, 1999, Food availability and the nocturnal vs. diurnal foraging trade-off in juvenile salmon: Journal of Animal Ecology, v. 68, p. 371-381.

Metcalfe, N. B., F. A. Huntingford, and J. E. Thorpe, 1988, Feeding Intensity, Growth Rates, and the Establishment of Life-History Patterns in Juvenile Atlantic Salmon Salmo salar: Journal of Animal Ecology, v. 57, p. 463-474.

Murray, B. W., H. Sultmann, and J. Klein, 1999, Analysis of a 26-kb region linked to the Mhc in zebrafish: genomic organization of the proteasome component beta/transporter associated with antigen processing- 2 gene cluster and 
identification of five new proteasome beta subunit genes.: Immunology, v. 163, p. 2657-2666.

Narum, S. R., J. s. Zendt, and C. Frederiksen, 2011, Candidate Genetic Markers Associated with Anadromy in Oncorhynchus mykiss of the Klickitat River, Transaction of the American Fisheries Society, p. 843-854.

Nichols, K. M., A. F. Edo, P. A. Wheeler, and G. H. Thorgaard, 2008, The Genetic Basis of Smoltification-Related Traits in Oncorhynchus Mykiss: Genetics Society of America, v. 179, p. 1559-1575.

Pauly, D., W. Trites, E. Capuli, and V. Christensen, 1998, Diet composition of trophic levels of marine mammals: ICES Journal of Marine Science, v. 55, p. 467-481.

Peven, C. M., R. R. Whitney, and K. R. Williams, 1994, Age and Length of Steelhead Smolts from the Mid-Columbia River Basin, Washington: North American Journal of Fisheries Management, v. 14, p. 77-86.

Pletnev, V. Z., T. S. Zamolodchikova, W. A. Pangborn, and W. L. Duax, 2000, Crystal structure of bovine duodenase, a serine protease, with dual trypsin and chymotrypsin-like specificities.: Proteins, v. 41, p. 8-16.

Quinn, T. P., 1993, A review of homing and straying in wild and hatchery produced salmon.: Fisheries Research, v. 18, p. 29-44.

Quinn, T. P., 2005, The Behavior and Ecology of Pacific Salmon \& Trout: Seattle, Wasington, University of Washington Press, 13-36 p.

Raymond, H. L., 1988, Effects of Hydroelectric Development and Fisheries Enhancement on Spring and Summer Chinook Salmon and Steelhead in the Columbia River Basin: North American Jounral of Fisheries Management, v. 8, p. $1-24$.

Roth, J. E., K. L. Mills, and W. J. Syderman, 2007, Chinook salmon (Oncorhynchus tshawytscha) - Seabird covariation off central California and possible forecasting applications.: Canadian Journal of Fisheries and Aquatic Sciences, v. 64, p. 10801090. 
Schroeder, K. R., R. B. Lindsay, and K. R. Kenaston, 2001, Origin and Staying of Hatchery Winter Steelhead in Oregon Coastal Rivers: Transactions of the American Fisheries Society, v. 130, p. 431-441.

Service, U. F. a. W., 2010, Summary and Overview of the US Fish and Wildlife Service Review of Federal Hatcheries in the Pacific Region: A Road Map to the Future, in P. R. U. F. a. W. S. Hatchery Review Team, ed., Portland, Oregon.

Stearly, R. F., and S. G. R., 1993, Phylogeny of the Pacific Trouts and Salmons (Oncorhynchus) and Genera of the Family Salmonidae: Transactions of the American Fisheries Society, v. 122, p. 1-33.

Stearns, S. C., 1989, The evolutionary significance of phenotypic plasticity: BioScience, v. 39 , p. 436-445.

Tattam, I. A., 2006, Seasonal Life History of Oncorhynchus mykiss in the South Fork John Day River Basin, Oregon, Oregon State University.

Thrower, F. P., J. J. Hard, and J. E. Joyce, 2004, Genetic architecture of growth and early life-history transistions in anadromous and derived freshwater populations of steelhead: Journal of Fish Biology, v. 65, p. 286-307.

Wipfil, M. S., J. P. Hudson, and J. P. Caouette, 2003, Marine Subsides in Freshwater Ecosystems: Salmon Carcasses Increase the Growth Rate of Stream-Resident Salmonids: Transactions of the American Fisheries Society, v. 132, p. 371-381.

Zimmerman, C. E., and G. H. Reeves, 2000, Population structure of sympatric anadromous and nonanadromous Oncorhynchus mykiss: evidence from spawning surveys and otolith microchemistry, Canadian Journal of Fisheries and Aquatic Sciences, p. 2152-2162.

Zimmerman, C. E., and G. H. Reeves, 2002, Identification if steelhead and resident rainbow trout progency in the Deschutes River, Oregon, revealed with otolith microchemistry: Transactions of the American Fisheries Society, v. 131, p. 986993. 